\title{
APORTACIONES AL CONOCIMIENTO DEL GENERO SALIX L. (SALICACEAE) EN LA PROVINCIA DE LEON (NW ESPAÑA)
}

\author{
T.E. DIAZ GONZALEZ \& F. LLAMAS
}

\begin{abstract}
RESUMEN: Los autores han reconocido en el territorio estudiado 5 táxones del subgénero Salix y 7 del subgénero Vetrix así como 16 híbridos. Consideran a S. neotricha una especie independiente de S. fragilis. Se describen los siguientes hibridos: Salix $x$ expectata, Salix $x$ pormensis, Salix $x$ viridifolia, Salix $x$ pseudosalvifolia, Salix $x$ longissima, Salix $x$ pseudoelaeagnos, Salix $\times$ multidentata y Salix $x$ rijosa.

De cada taxon se aporta la distribución en la provincia de León en base a la cartografia UTM de $10 \mathrm{~km}$ de lado, así como su comportamiento fitosociológico.

Se aportan tres claves dicotómicas para la diferenciación de los táxones del género Salix en la provincia de León basándose en los amentos masculinos y femeninos, asi como la morfología foliar.
\end{abstract}

ABSTRACT: The autors have recognized in the studied territory 5 taxa of the Salix subgenus and 7 of the Vetrix subgenus as well as sixteen hybrids. They consider S. neotricha an independent species from S. fragilis. The following hybrids are described: Salix $x$ expectata, Salix x pormensis, Salix x viridifolia, Salix x pseudosalvifolia, Salix x longissima, Salix $x$ pseudoelaeagnos, Salix $x$ multidentata and Salix $x$ rijosa.

We give the chorology of each taxon in León province on maps with UTM coordinates of 10 $\mathrm{km}$, as well as its phytosociological behaviour.

Three dichotomic keys are given in order to identify the taxa of the Salix genus living in León province. These are based on male and female catkins as well as leaf morphology.

\section{INTRODUCCION}

Para la realización del presente estudio, se planificaron una serie de muestreos en el campo con el fin de abarcar la mayor parte de la compleja red hidrográfica de la provincia de León desde finales del invierno hasta el otoño, con el fin de recoger material con una doble finalidad: precisar el área de distribución de cada taxon y disponer de plantas con amentos y con hojas adultas. 
Los materiales se han recolectado en las redes hidrográficas del río Esla y Valderaduey ambos en la margen derecha del río Duero, así como los de la red hidrográfica del río Sil, perteneciente a la cuenca del Miño.

Por otra parte este estudio está referido exclusivamente a los sauces que tienen un hábitat, como ya se ha explicado, en los márgenes de los ríos o en los bosques ribereños, por 10 cual no se ha tenido en cuenta Salix breviserrata, planta propia de las comunidades orocantábricas, calcícolas, quionófilas, subalpino-alpinas de rocas criofractadas (Rivas-Martínez \& col., 1984) perteneciente al subgénero Chamaetia ni el recientemente descrito Salix repens subsp. picoeuropeana Lainz, propio de las comunidades turfófilas de las dolinas picoeuropeanas (Argüelles \& col., 1984) perteneciente al subgénero Vetrix. Tampoco se ha tenido en cuenta el complejo de los sauces cultivados como ornamentales (Salix babilonica y sus afines).

Para la identificación inicial de los táxones nos hemos basado fundamentalmente en los criterios expuestos por Vicioso (1951), Görz (1926, 1930), F.U. Rechinger (1957), K.U. Rechinger (1964), Meikle (1984), Skvortsov (1968).

Los tipos y lectótipos de los táxones supraespecificos corresponden a los propuestos por Skvortsov (1968).

Consideramos que para delimitar los táxones del género Salix pueden utilizarse como buenos caracteres, debido a 1 a constancia que hemos observado en los mismos, los siguientes: morfologia de las hojas adultas, filotaxia, tipologia de los tricomas y distribución de. los mismos, no de filamentos estaminados, concrescencia o no de los mismos, morfología y pigmentación de las brácteas florales. Dichos caracteres han sido utilizados en la confección de las claves de identificación que aportamos.

La distribución de cada taxon se basa en el material recolectado, así como el referido en Puente (1985), que se encuentran depositados en el herbario de la Facultad de Biología de León ( LEB).

Para la caracterización fitosociológica de los distintos táxones hemos seguido los criterios de Díaz \& Penas (1986) y Díaz \& col. (1986).

Para la ordenación de los táxones estudiados seguimos los criterios de Skvortsov (1968).

CLAVES PARA LA IDENTIFICACION DE LOS SAUCES

DE LA PROVINCIA DE LEON

I. Mediante las hojas

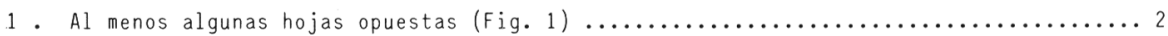

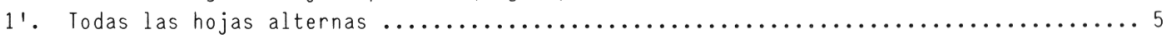

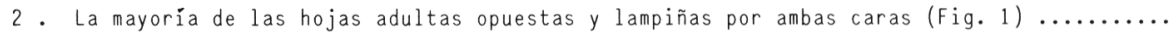

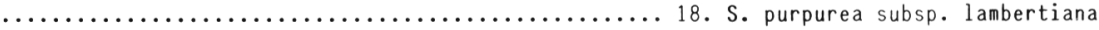

2'. La mayoría de las hojas adultas alternas y pubescentes al menos por el envés (Fig. 2)..3 

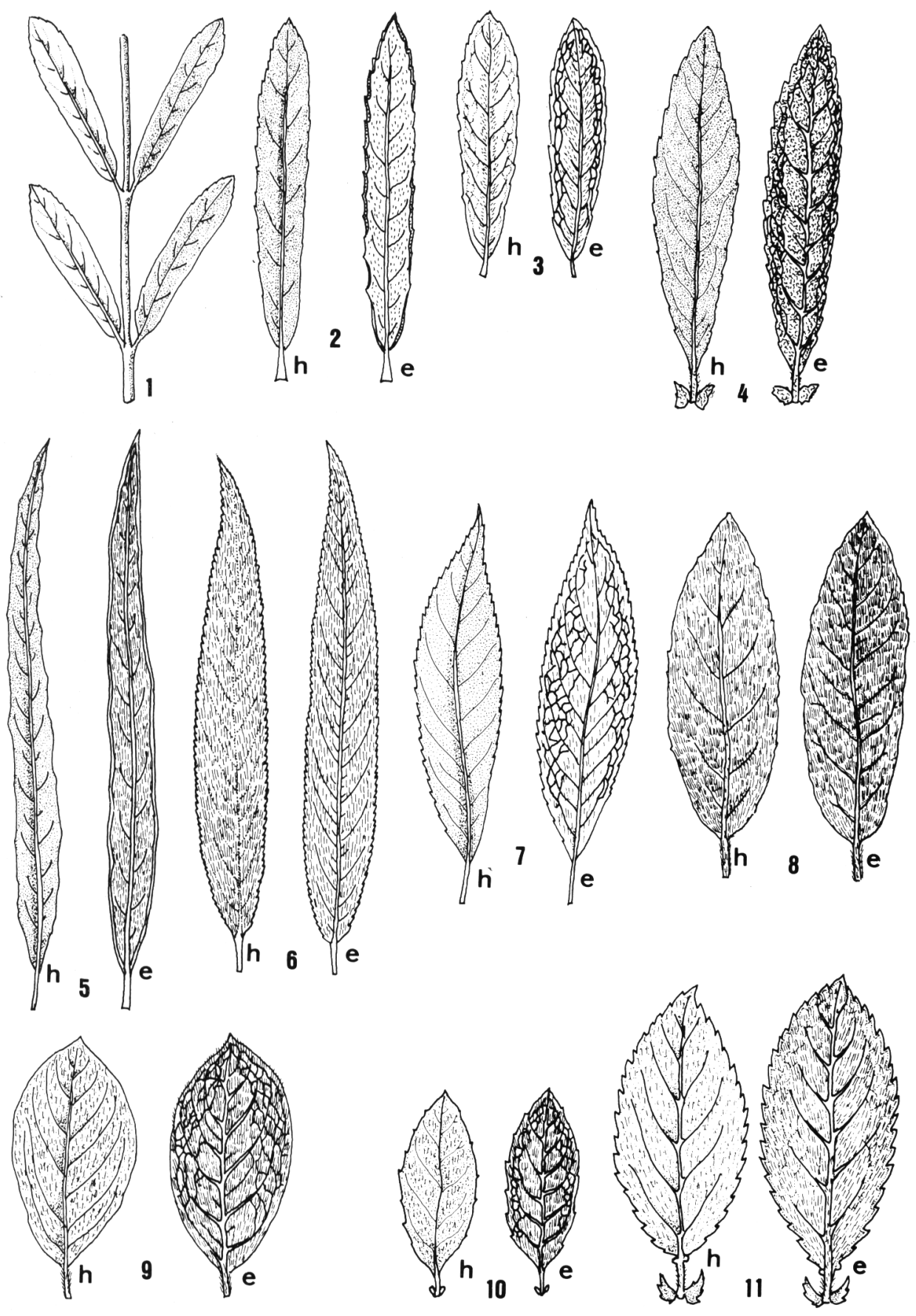
3. Hojas de $5-10$ veces tan largas como anchas (Fig. 2) ......... 25. S. x pseudoelaeagr

3'. Hojas de $1-5$ veces tan largas como anchas (Fig. 3-4)

4. Hojas provistas de algún pelo rojizo-ferrugineo (Fig. 3) .......... 23. S. x viciosor

4'. Hojas desprovistas de pelos rojizo-ferrugíneos (Fig. 4) .......... 22. S. x matritens

5 - Hojas adultas con algún pelo adpreso-seríceo al menos por el envés (Fig. 5-14) .....6

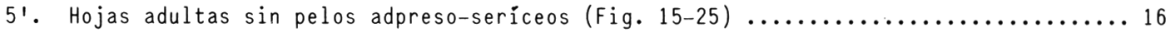

6 . Hojas lineares, linear-lanceoladas o lanceoladas, de más de 5 veces tan largas como

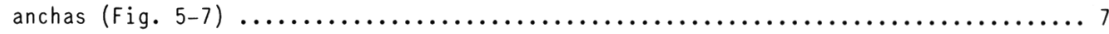

6'. Hojas ovadas, obovadas, oblongas, elipticas o suborbiculares menos de 5 veces tan largas

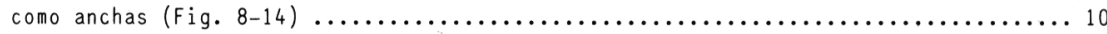

7. Hojas lineares o linear-lanceoladas con márgenes aparentemente enteros y con un tomento denso de pelos sericeos brillantes por el envés (Fig. 5) ............ 16. S. viminalis

7'. Hojas lanceoladas con los márgenes regularmente aserrados (Fig. 6-7) ........... 8

8. Hojas adultas densamente cubiertas de pelos seríceos por el envés (Fig. 6) .. 2. S. alba

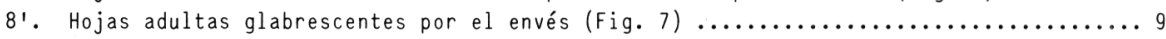

9. Hojas largamente acuminadas, a veces con glándulas simples en la unión del peciolo con

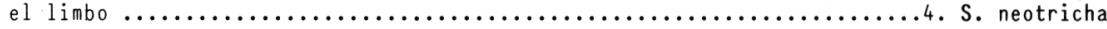

9'. Hojas cortamente acuminadas sin glándulas en la zona de unión del peciolo con el limbo

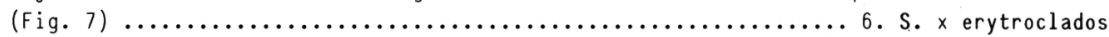

10 . Hojas adultas densamente adpreso-sericeas brillantes por ambas caras (Fig. 8) ..........

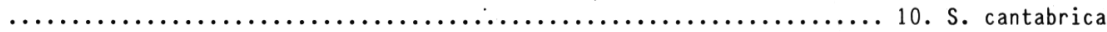

10'. Hojas adultas adpreso-seríceas brillanteș sólo por el envés, o bién por ambas caras pero en este caso el tomento mucho más denso por el envés (Fig. 9-14) $\ldots \ldots \ldots \ldots \ldots \ldots \ldots 11$

11. Haz de las hojas adultas glabrescente, generalmente con algún pelo rojizo-ferrugíneo en

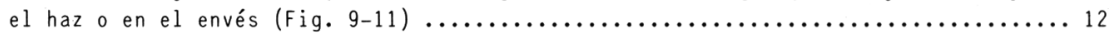

11'. Haz de las hojas adultas tomentoso, sin pelos rojizo-ferrugíneos (Fig. 12-14) ..... 14 -

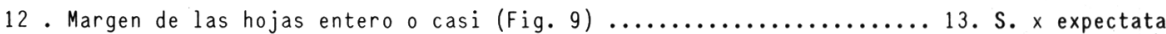

12'. Margen de las hojas netamente dentado o dentado-glanduloso (Fig. 10-11) ...........13

13. Envés de las hojas densamente cubierto de pelos seríceos adpresos (fig. 10)

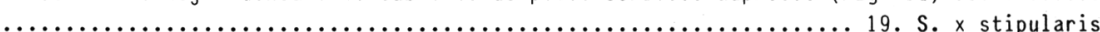

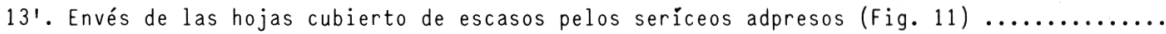

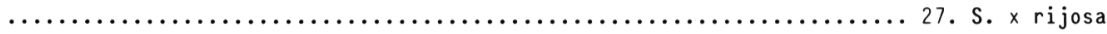

14. Hojas con el haz verde claro (Fig. 12) 20. S. x viridifolia

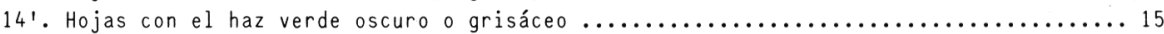

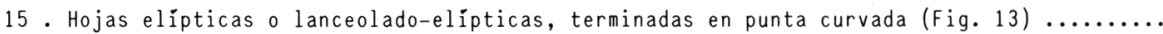

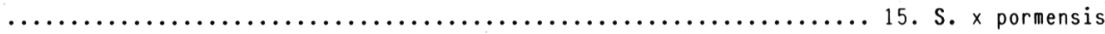

15'. Hojas lanceoladas u oblongo-lanceoladas (Fig. 14) ............ 14. S coenocarpetana

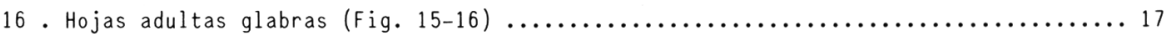

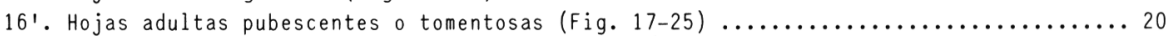

17. Con glándulas más o menos ramificadas en la zona de unión del limbo con el peciolo (Fig.

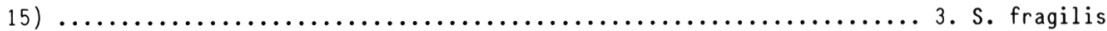

17'. Sin glándulas más o menos ramificadas en la zona de unión del limbo con el peciolo (en

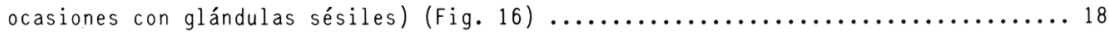



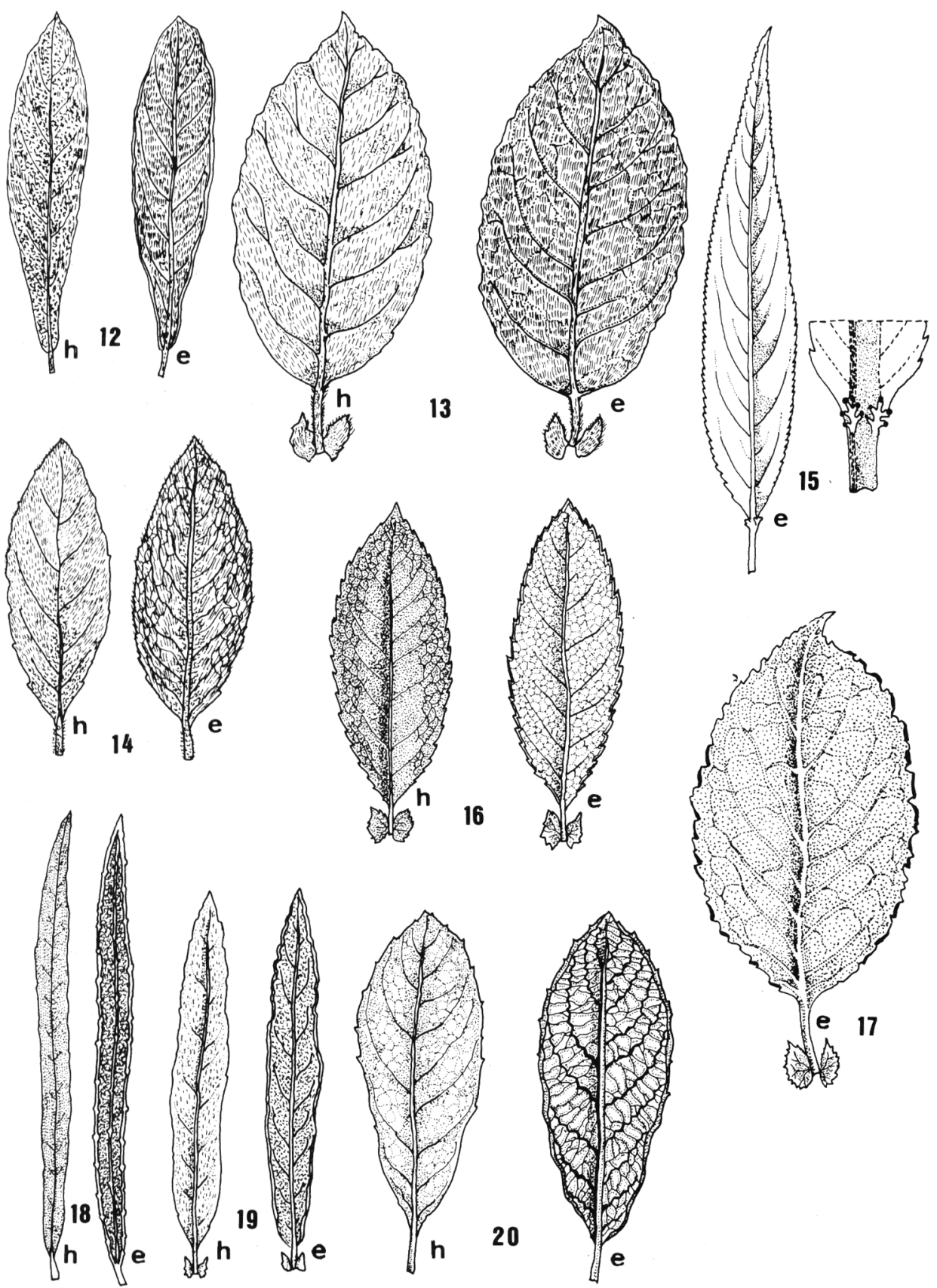
18. Estípulas persistentes, grandes, auriculadas, con los márgenes aserrado-glandulosos

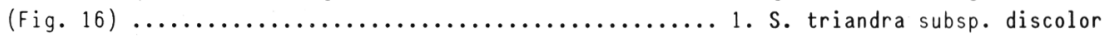

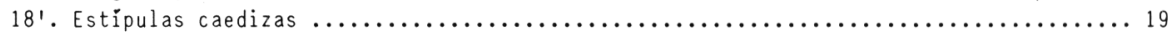

19. Hojas largamente acuminadas, generalmente con glándulas sésiles en la zona de unión del

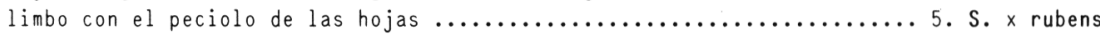

19'. Hojas cortamente acuminadas, sin glándulas sésiles en la zona de unión del limbo con el

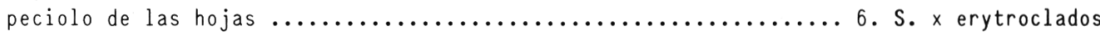

20. Hojas grandes de 5-14 × 2-8 cm, elipticas, orbiculares 0 anchamente ovales, con el envés

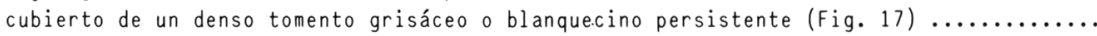

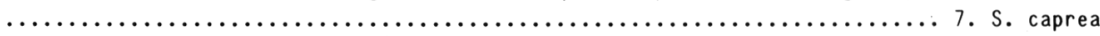

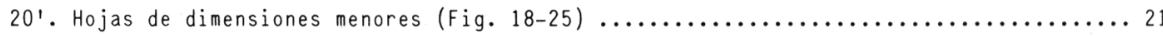

21. Hojas lineares o linear-lanceoladas, de 10-15 veces tan largas como anchas, con el envés blanco-tomentoso (Fig. 18) ........................ elaeagnos subsp. angustifolia

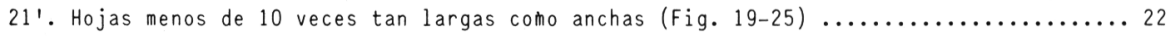

22. Hojas brillantes por el envés (Fig. 19) ...................... 24. Songissima

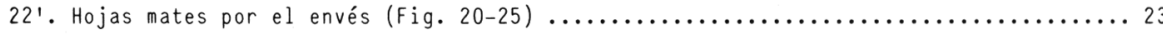

23. Hojas adultas glabras o glabrescentes y lustrosas por el haz, generalmente con algún

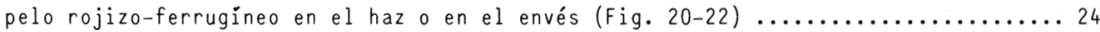

23'. Hojas adultas pubescentes 0 tomentosas por el haz, generalmente sin pelos

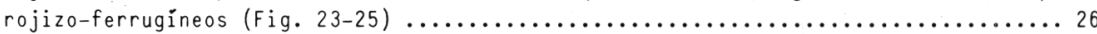

24 . Margen de las hojas entero o con dientes no netos (Fig. 20) ........ 9. S. atrocinerea

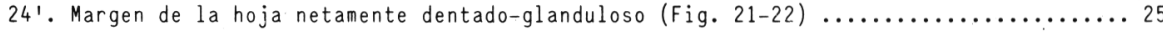

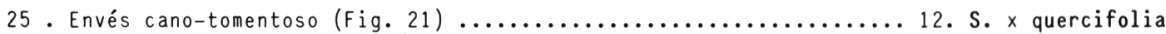

25'. Envés con ligera pubescencia de pelos rojizos o blanquecinos (Fig. 22) $\ldots \ldots \ldots \ldots \ldots \ldots$ ................................................. S. $x$ multidentata

26. Hojas con un denso tomento blanquecino o grisáceo por ambas caras y más o menos

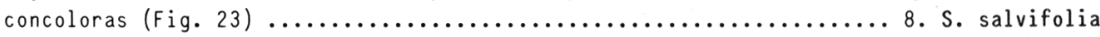

26'. Hojas discoloras, con el haz más o menos verde y el envés tomentoso grisáceo o

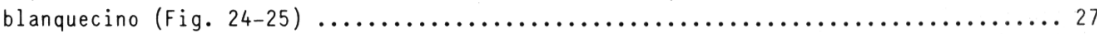

27. Hojas linear-lanceoladas o lanceoladas (Fig. 24) ..............21. S. pseudosalvifolia 27'. Hojas elíptico-trasovadas u oblongo-trasovadas (Fig. 25) .......... 11. S. x secalliana

\section{Mediante individuos masculinos}

1. Flor masculina con un filamento estaminal terminado por 1 ó 2 anteras. 1 ó 2 nectarios

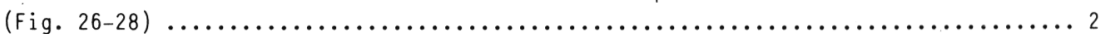

1'. Flor masculina con más de un filamento estaminal (Fig. 29-53) $\ldots \ldots \ldots \ldots \ldots \ldots \ldots \ldots$

2. Todos los amentos opuestos. La mayoría de las hojas opuestas aserradas, no glandulosas, glabras. Anteras al principio rojas, después negruzcas. 1 nectario (Fig. 1 y 26 ) .......

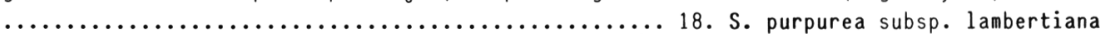

2'. Amentos y hojas todos alternos o con algunos alternos y otros opuestos. 1 ó 2 nectarios.

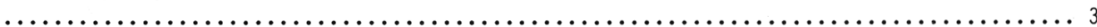



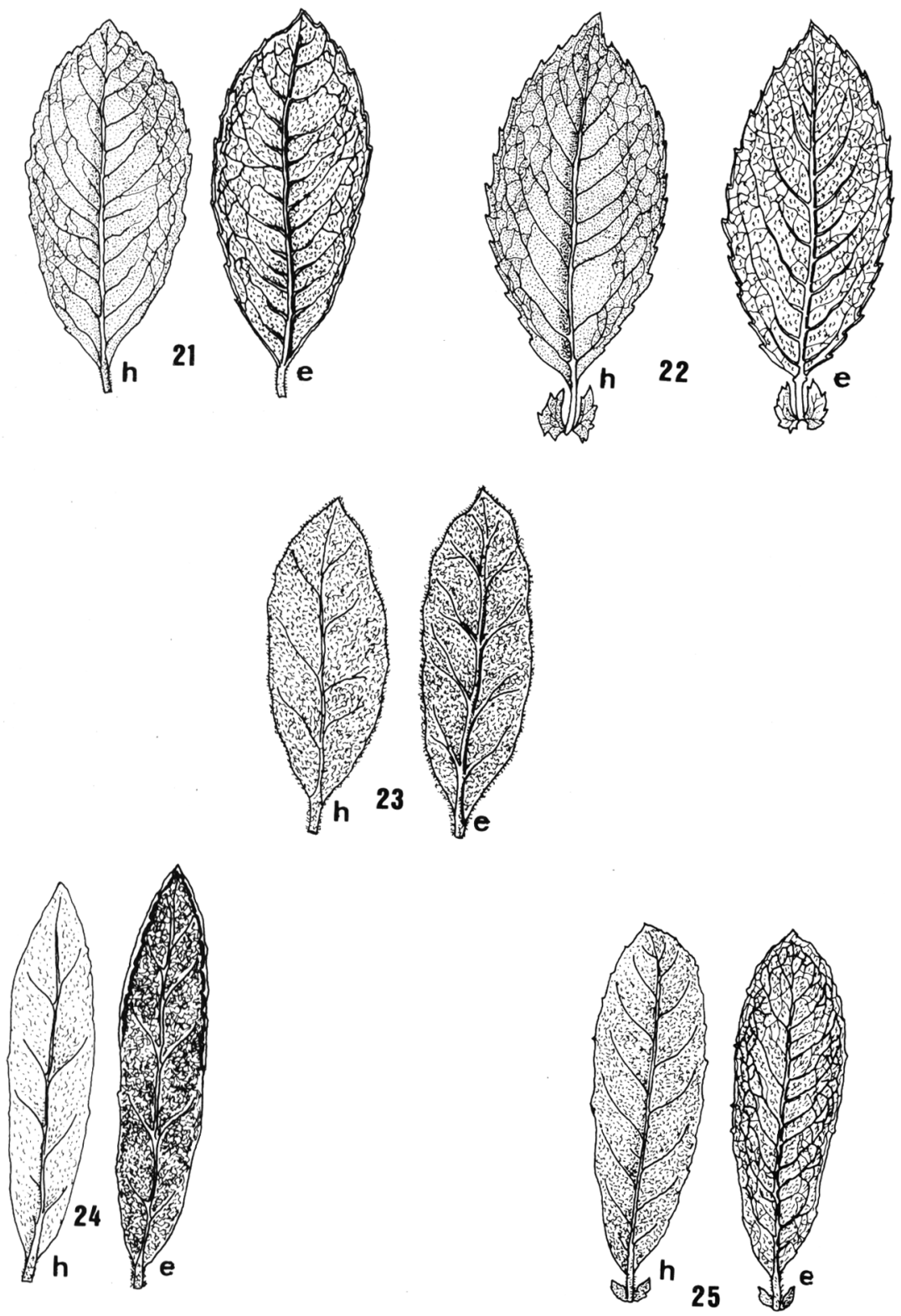

Figuras $21-25$ 
3. Filamentos estaminales con dos anteras (en un mismo amento pueden aparecer flores con 2 ó 3 filamentos estaminales). Hojas sedoso-plateadas por el envés (Fig. 11 y 27) $\ldots \ldots \ldots$

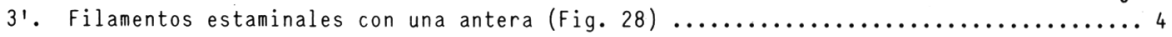

4. Algunas hojas y amentos opuestos. 1 nectario (Fig. 3) ............ 23. S. x viciosorum

4'. Todas las hojas y amentos alternos. 2 nectarios (Fig. 7 y 28) .... 6. S. x erytroclados

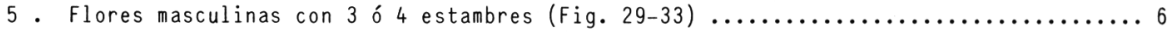

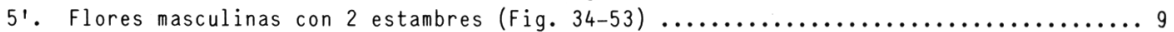

6. Amentos con todas las flores provistas de 3 estambres. 2 nectarios. Hojas adultas glabras con estípulas persistentes, grandes arriñonado-dentadas (Fig. 16 y 29) ........

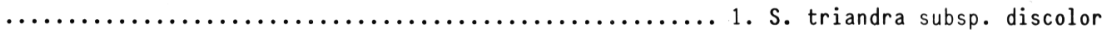

6'. Amentos con las flores provistas de 3 ó 4 (raramente 1 ó 2) estambres (Fig. 30-33) ... 7

7. Hojas adultas con el envés cubierto de pelos sedoso-brillantes aplicados. 1 nectario

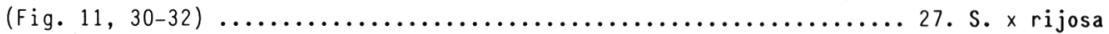

7'. Hojas adultas lampiñas o glabrescentes por el envés. 2 nectarios (Fig. 7 y 33 ) ..... 8

8. Sin glándulas ramificadas en el punto de unión del limbo con el peciolo de la hoja (Fig.

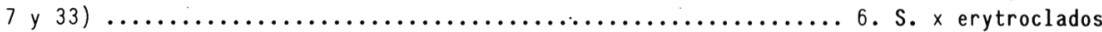

8'. Con glándulas más o menos ramificadas en el punto de unión del limbo con el peciolo de

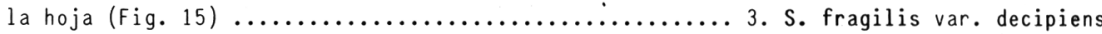

9. Estambres con los filamentos libres desde la base. 1 ó 2 nectarios (Fig. 34-41) .... 10

9'. Estambres con los filamentos soldados parcialmente. 1 nectario, raramente 2 (Fig. 45-53)

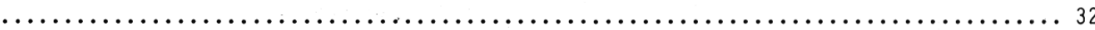

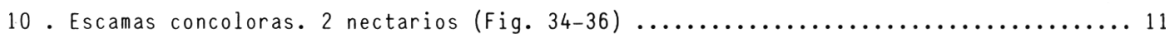

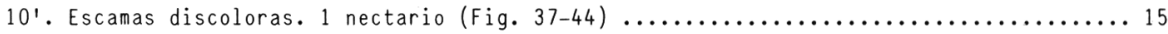

11. Peciolo de las hojas adultas con glándulas ramificadas o sésiles en el punto de unión

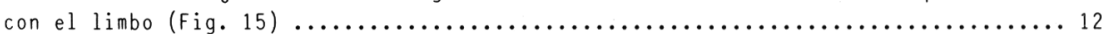

11'. Peciolo de las hojas adultas sin glándulas en el punto de unión con el limbo (Fig. 6 y

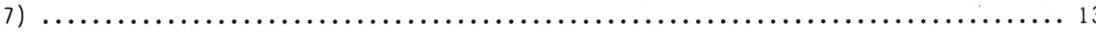

12. Hojas adultas lampiñas, asi como el peciolo que mide 10-22 mm de longitud. Con glándulas ramificadas en el punto de unión del peciolo con el limbo (Fig. 15 y 34 ) .............

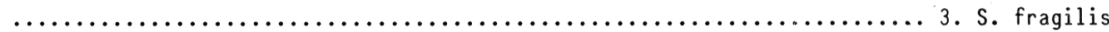

12'. Hojas adultas lampiñas o glabrescentẻs, con el peciolo pubescente que mide de $2-8 \mathrm{~mm}$ de longitud, generalmente con glándulas sésiles en el punto de unión del peciolo con el

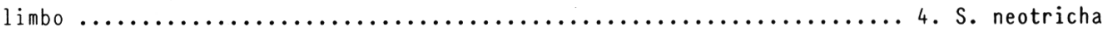

13. Hojas adultas cubiertas por el haz y el envés de pelos sedoso-aplicados. Yemas adcultas

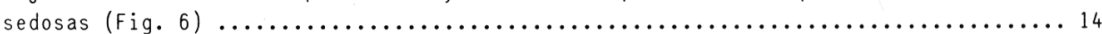

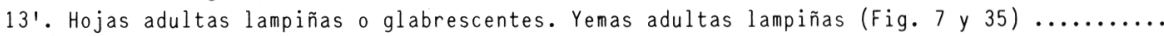

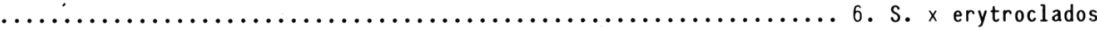

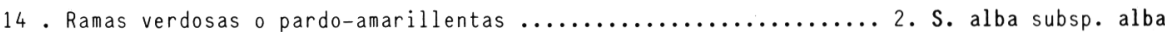
14'. Ramas amarillo-doradas o rojizas ..................... S. alba subsp. vitellina

15. Hojas adultas, al menos por el envés, con un tomento de pelos seríceos generalmente

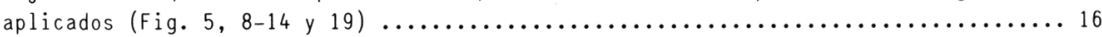

15'. Hojas adultas nunca con pelos seríceos aplicados (Fig. 3,17 y 20-25) .......... 24

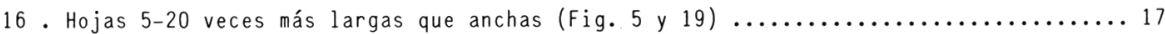

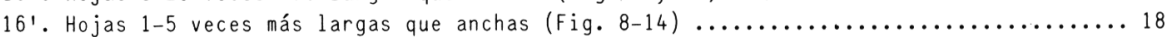



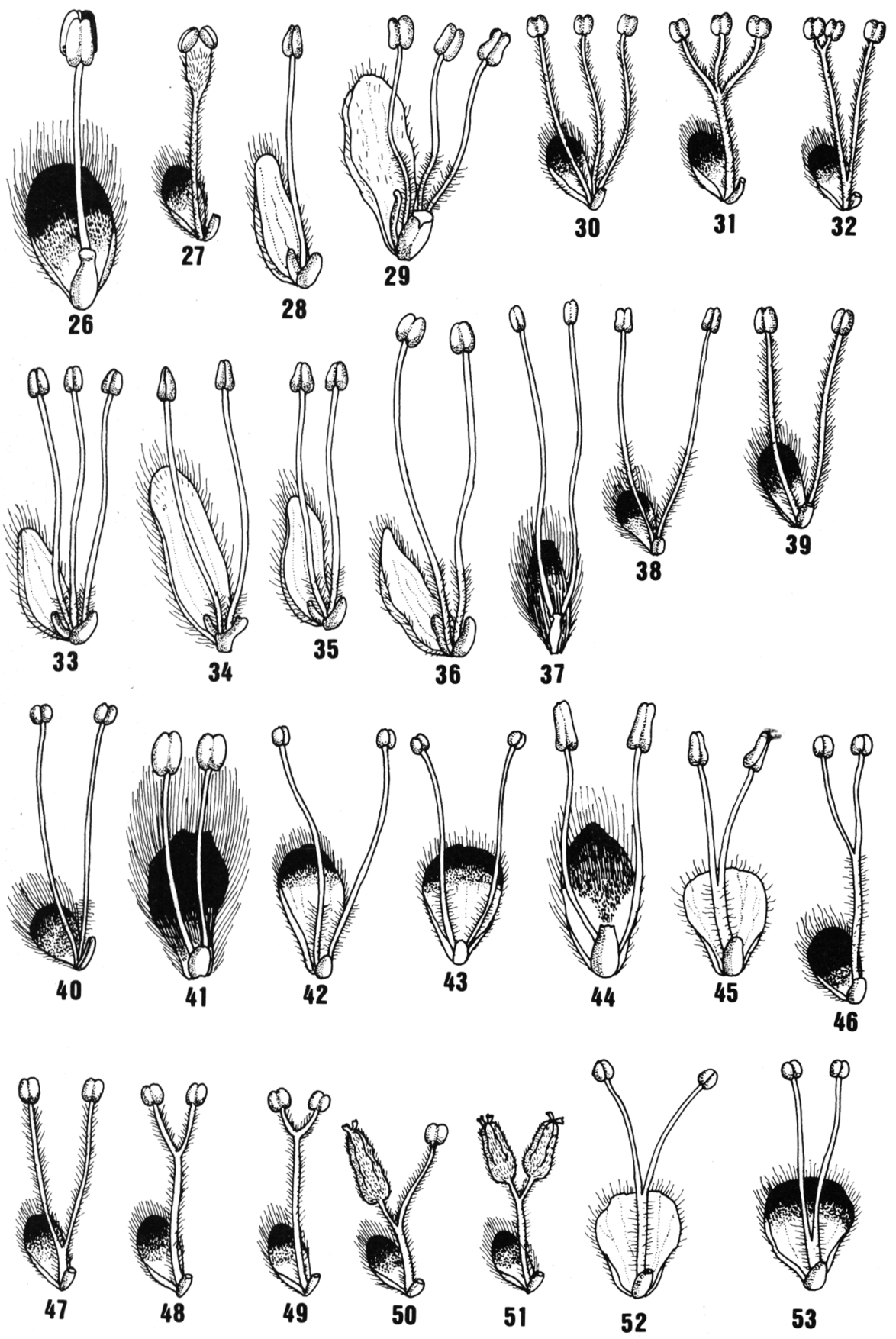
17. Hojas adultas con el envés densamente cubierto de pelos seríceos aplicados (Fig. 5 y 37 )

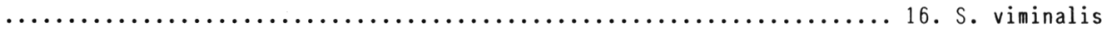

17'. Hojas adultas con el envés cubierto de pelos no aplicados ........24. S. x longissima

18. Hojas adultas con el haz y el envés cubiertos únicamente por pelos seríceos aplicados

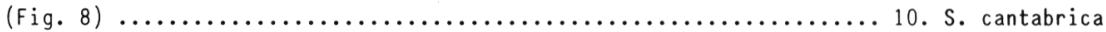

18'. Hojas adultas con el haz sin pelos sericeos aplicados, o bien con una mezcla de pelos

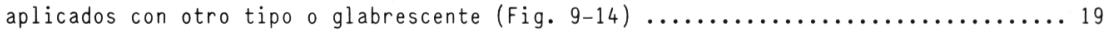

19. Hojas adultas con algunos pelos rojizo-ferrugíneos o amarillentos en el haz o envés. Haz

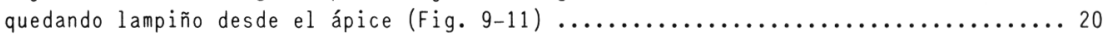

19'. Hojas sin pelos rojizo-ferrugíneos o amarillentos. Haz siempre pubescente (Fig. 12-24)..

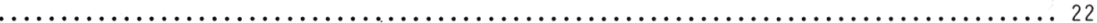

20. Envés densamente cubierto de pelos sericeos aplicados (Fig. 10) ... 19. S. x stipularis 20'. Envés con un tomento ralo de pelos sericeos aplicados (Fig. 9 y 11) $\ldots \ldots \ldots \ldots \ldots \ldots 21$

21. Todas las flores con dos estambres (Fig. 9 y 38) ................. . . x expectata

21'. Flores con 1, 2 ó 3 estambres y anormalidades (reemplazamiento de anteras por ovarios,

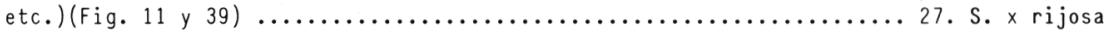

22. Escamas con ápice negro y base más o menos rosada (Fig. 12 y 40) .. 27. S. x viridifolia

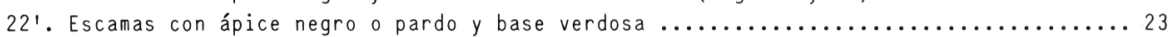

23. Hojas elípticas o lanceolado-elipticas,terminando en punta curva (Fig. 13) . H. xpormensis

23'. Hojas lanceoladas u oblongo-lanceoladas (Fig. 14) ............. 14. x coenocarpetana

24. Hojas de 5-14 x 2-8 cm, elípticas, orbiculares o anchamente ovales, con el envés cubierto de un denso tomento grisáceo o blanquecino persistente (Fig. 17 y 41 ) .......

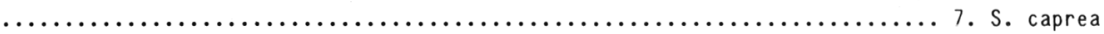

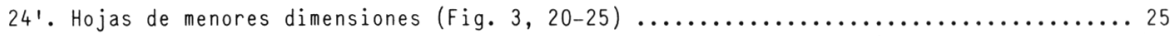

25 . Hojas adultas con haz y envés provisto de un tomento más o menos denso, grisáceo 0

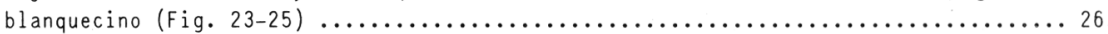

25'. Hojas adultas con haz pubescente o glabro y envés tomentoso o pubescente. Con frecuencia aparecen pelos rojizo-ferrugíneos o amarillo-rojizos (Fig. 3, 20-22) .............28

26. Hojas casi concólores (haz y envés con tomento grisáceo o blanquecino)(Fig. 23 y 42 )....

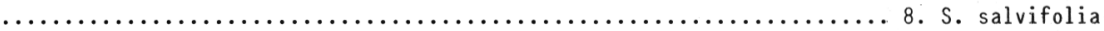

26'. Hojas netamente discoloras (haz más 0 menos verdoso y envés grisáceo 0

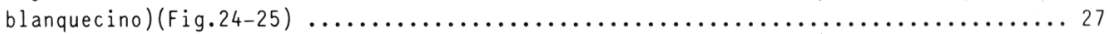

27. Hojas linear-lanceoladas o lanceoladas (Fig. 24 y 43) ...... 21. S. x pseudosalvifolia 27'. Hojas eliptico-trasovadas u oblongo-trasovadas (Fig. 25) .......... 11. S. x secalliana

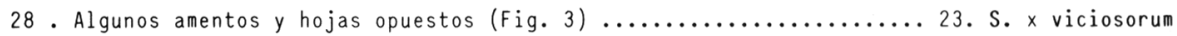

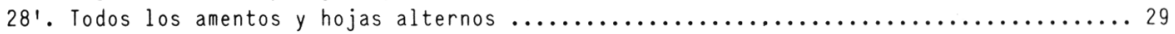

29. Haz de las hojas adultas lampiño o ligeramente glabrescente (Fig. 20-22) ......... 30 29'. Haz de las hojas adultas más o menos tomentoso (Fig. 25) .......... . . . x secalliana

30 . Margen de las hojas casi entero (Fig. 20 y 44) .................. S. atrocinerea

$30^{\prime}$. Margen de las hojas netamente dentado-glanduloso (Fig. 21-22) $\ldots \ldots \ldots \ldots \ldots \ldots \ldots . \ldots . \ldots . \ldots$

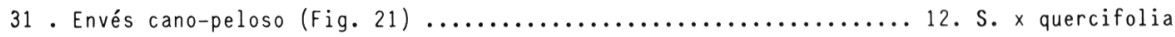

$31^{\prime}$. Envés con ligera pubescencia de pelos rojizos o blanquecinos (Fig. 22) $\ldots \ldots \ldots \ldots \ldots \ldots$

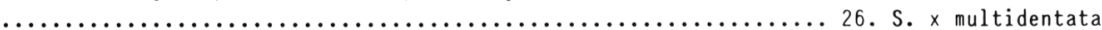



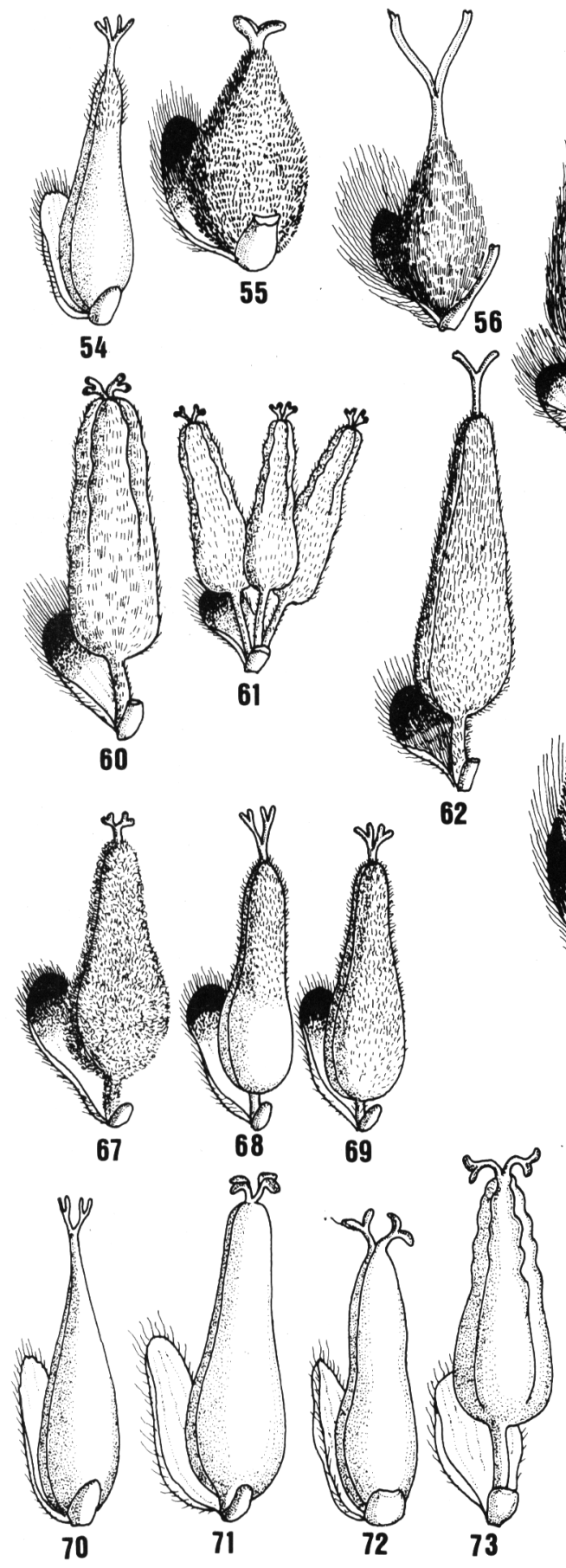
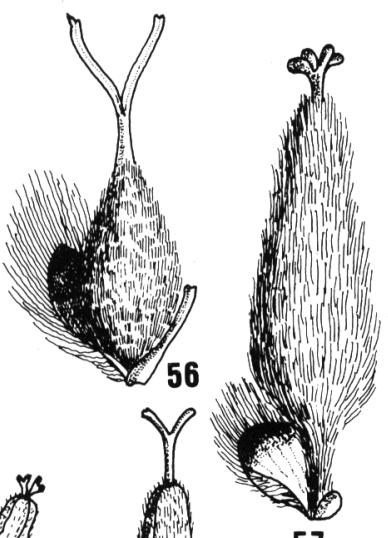

57
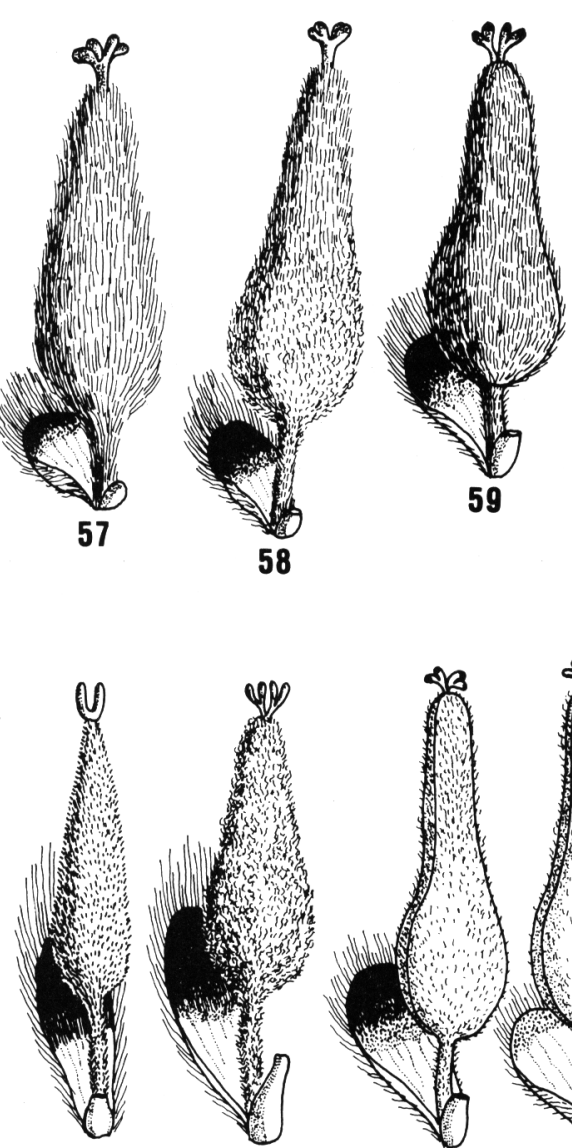

63

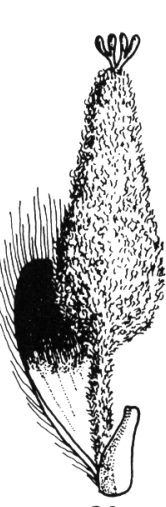

64
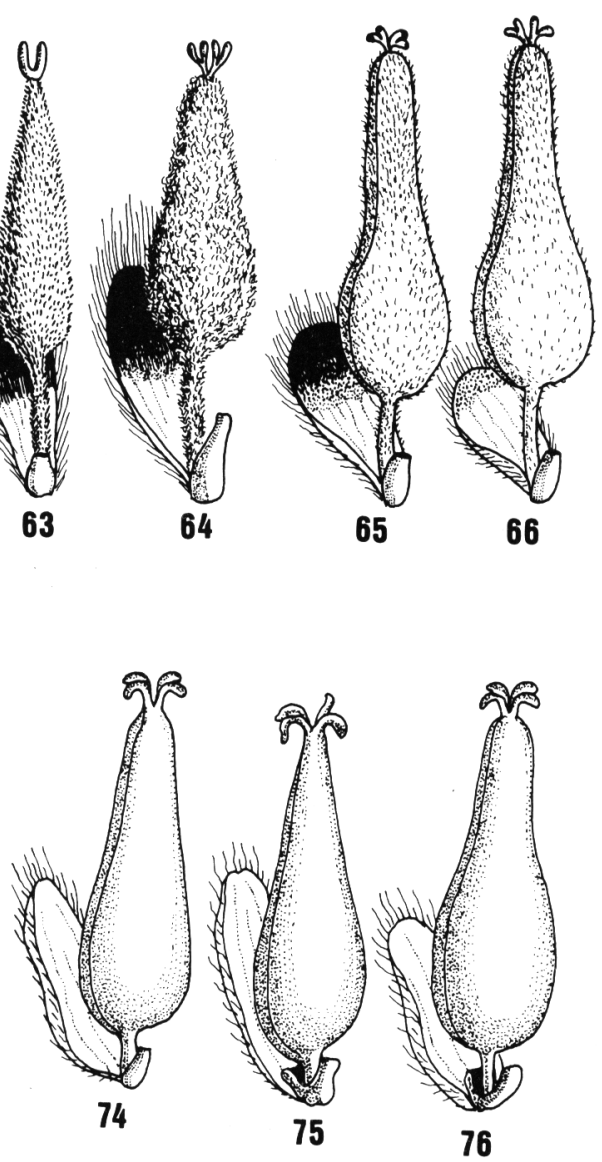

Figuras $54-76$ 
32 . Un nectario

32'. Dos nectarios

3. S. fragilis

33. Hojas largas (10-15 veces tan largas como anchas). Envés blanco-tomentoso y haz verde

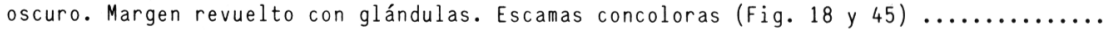

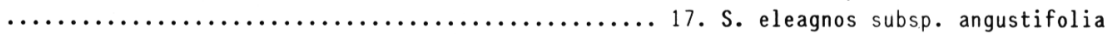
$3^{\prime}$. Hojas cortas $(1-10$ veces tan largas como anchas) (Fig. 2-4, 11 y 24) ........... 34

34. Hojas con haz verde brillante, casi glabras y envés glauco más o menos tomentoso. Algunos amentos y hojas opuestos (Fig. 2 y 46) $\ldots \ldots \ldots \ldots \ldots 25$. S. x pseudoelaeagnos $34^{\prime}$. Hojas con ambas caras pubescentes o tomentosas (Fig. $3-4,11$ y 24$) \ldots \ldots \ldots \ldots \ldots . \ldots 35$

35 . Envés con todos o algunos pelos seríceos aplicados (Fig. 11 y 47-51) ... 27. S. x rijosa

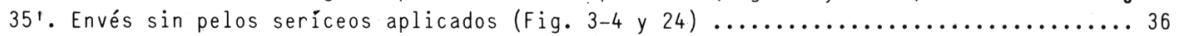

36 . Todas las hojas y amentos alternos (Fig. 24 y 52-53) ....... 21. S. x pseudosalvifolia

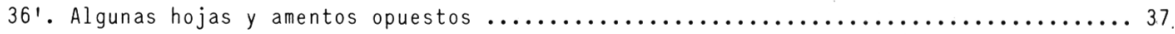

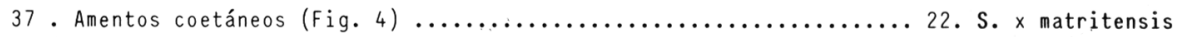
37'. Amentos precoces (Fig. 3) 23. S. x viciosorum

\section{Mediante individuos femeninos}

1. Ovario o cápsula total o parcialmente tomentoso o pubescente. 1 nectario. Escamas

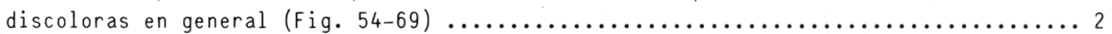

1'. Ovario o cápsula totalmente lampiños. 1 ó 2 nectarios. Escamas concoloras (Fig. 70-76)..

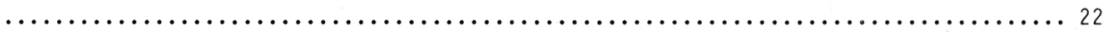

2. Ovario o cápsula sésil o subsésil (pedúnculo más corto que el nectario)(Fig. 54-56) .. 3

2'. Ovario o cápsula pedunculada (pedúnculo más largo que el nectario) (Fig. 57-69) ..... 5

3. Ovario parcialmente glabro (Fig. 54)

21. S. x pseudosalvifolia

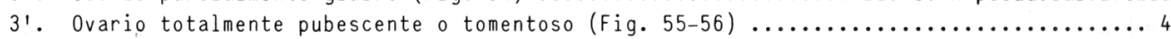

4. Amentos y hojas opuestos (Fig. 1 y 55) ........... 18. S. purpurea subsp. lambertiana

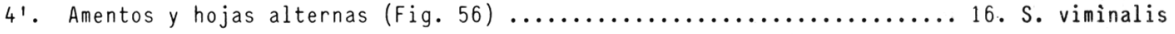

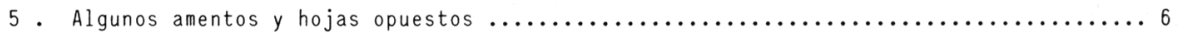

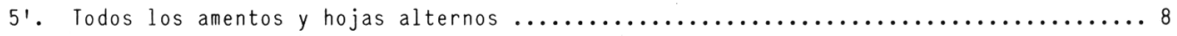

6 . Amentos precoces. Hojas adultas lampiñas por el haz y algo pubescentes por el envés, con

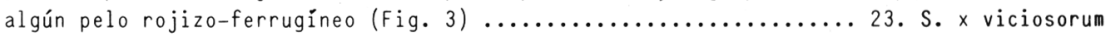

$6^{\prime}$. Amentos coetáneos. Hojas sin pelos rojizo-ferrugíneos $\ldots \ldots \ldots \ldots \ldots \ldots \ldots \ldots \ldots \ldots \ldots$

7. Hojas adultas de 5-10 veces tan largas como anchas (Fig. 2) ... 25. S. x pseudoelaeagnos

7'. Hojas adultas de $1-5$ veces tan largas como anchas (Fig. 4) ...... 22. S. x matritensis

8. Hojas adultas, al menos por el envés, con un denso tomento de pelos seríceos

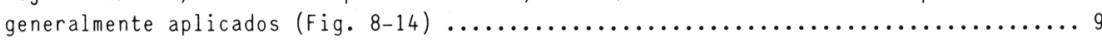

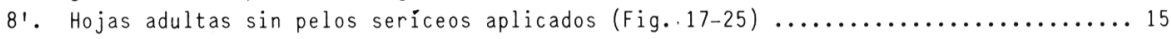

9. Hojas adultas plateado-brillantes por ambas caras (Fig. 8 y 57) ..... 10. S. cantabrica

9'. Hojas adultas plateado-brillantes sólo por el envés $($ Fig. 9-14) .................. 10 
10. Haz de las hojas adultas glabrescente, generalmente con algún pelo rojizo-ferrugíneo

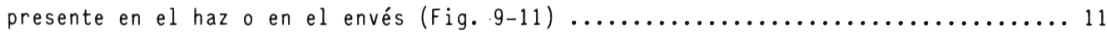

10'. Haz de las hojas adultas tomentoso, sin pelos rojizo-ferrugíneos (Fig. 12-14) ..... 13

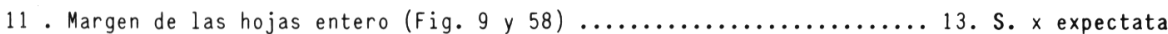

11'. Margen de las hojas netamente dentado o dentado-glanduloso (Fig. 10-11) .......... 12

12. Hojas con el envés densamente cubierto de pelos seríceos adpresos (Fig. 10)

12'. Hojas con el envés cubierto de algún pelo seríceo-adpreso (Fig. 11 y 59-61) ...........

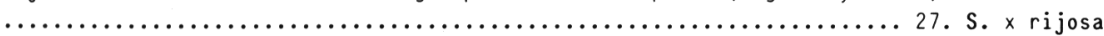

13. Escamas discoloras con el ápice negro o púrpura y la base verdosa ............. 14

13'. Escamas concoloras y/o discoloras con el ápice negro y la base más o menos rosada (Fig.

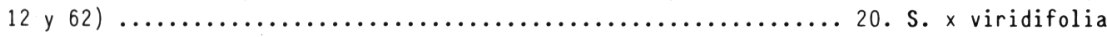

14 . Hojas elipticas o lanceolado-elipticas, terminadas en punta curvada (Fig. 13)

14'. Hojas lanceoladas u oblongo-lanceoladas (Fig. 14) ........... 14. S. x coenocarpetana

15. Hojas de 5-14 × 2-8 cm, elípticas, orbiculares o anchamente ovales, con el envés

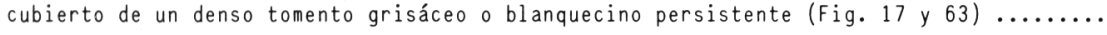

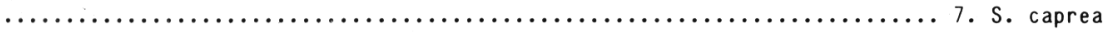

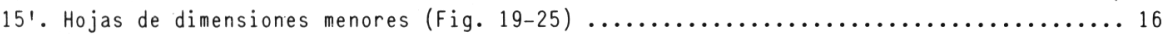

16. Hojas adultas brillantes por el envés (Fig. 19) $\ldots \ldots \ldots \ldots \ldots \ldots \ldots$ 24. S. x longissima

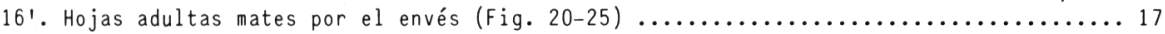

17. Hojas adultas glabrescentes por el haz y ligeramente pubescentes por el envés, con algún pelo rojizo-ferrugíneo mezclado con pelos blancos (Fig. 20 y 22) $\ldots \ldots \ldots \ldots \ldots \ldots \ldots 18$

17'. Hojas adultas pubescentes o tomentosas por el envés, generalmente sin pelos

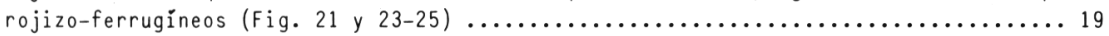

18. Margen de las hojas entero o con dientes no netos (Fig. 20 y 64) ... 9. S. atrocinerea

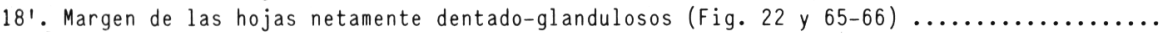

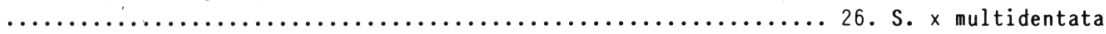

19. Hojas adultas con un denso tomento blanquecino o grisáceo por ambas caras, más o menos concoloras (Fig. 23 y 67) $\ldots \ldots \ldots \ldots \ldots \ldots \ldots \ldots \ldots \ldots \ldots \ldots \ldots \ldots \ldots \ldots \ldots \ldots \ldots \ldots \ldots \ldots \ldots \ldots$. S. salvifolia

19'. Hojas discoloras con el haz más o menos verde y el envés cano-peloso 0

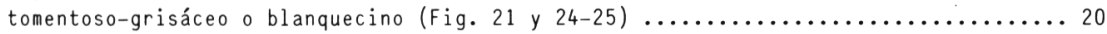

20. Envés cano-peloso (Fig. 21)

12. S. x quercifolia

20'. Envés tomentoso (Fig. 24-25) . 21

21 . Ovario parcialmente glabro (excepcionalmente totalmente pubescente). Margen de la hoja dentado-glanduloso al menos en el ápice (Fig. 24 y 68-69) ...22. S. x pseudosalvifolia

21'. Ovario totalmente pubescente. Margen de las hojas rizado-denticulado (Fig. 25).

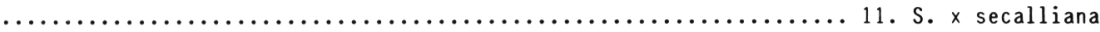

22. Ovario sésil o con el pedúnculo igual o más corto que el nectario (Fig. 70-72) ....23

22'. Ovario pedunculado (pedúnculo más largo que el nectario)(Fig. 73-76) ........... 26

23. Hojas adultas de $10-15$ veces $\tan$ largas como anchas (Fig. 18 y 70$) \ldots \ldots \ldots \ldots \ldots \ldots$

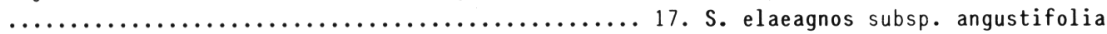

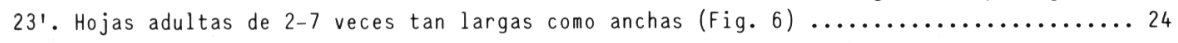


24 . Hojas adultas densamente cubiertas de pelos seríceos aplicados tanto en el haz como por

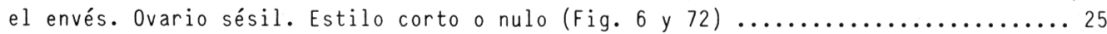

24'. Hojas adultas lampiñas o glabrescentes. Ovario cortamente pedunculado. Estilo corto

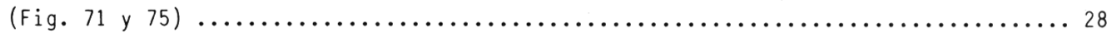

25 . Ramas verdosas 0 amarillo-castaño $\ldots \ldots \ldots \ldots \ldots \ldots \ldots \ldots \ldots \ldots \ldots \ldots \ldots \ldots \ldots \ldots$. S. alba subsp. alba 25'. Ramas amarillo-doradas o rojizas $\ldots \ldots \ldots \ldots \ldots \ldots \ldots \ldots \ldots \ldots \ldots \ldots \ldots \ldots \ldots \ldots$. S. alba subsp. vitellina

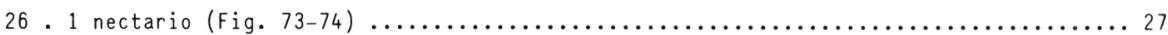

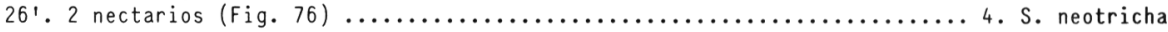

27. Hojas adultas totalmente lampiñas. Estípulas persistentes, grandes, auriculadas, dentado-glandulosas. Peciolo glabro (Fig. 16 y 73) ...... 1. S. triandra subsp. discolor

27'. Hojas adultas lampiñas o pubescentes. Estípulas caedizas, pequeñas. Peciolo pubescente

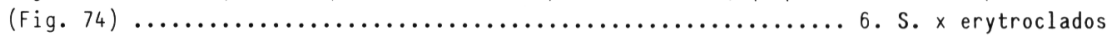

28. Hojas adultas glabrescentes, sin glándulas ramificadas en la unión del limbo con el

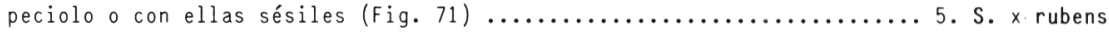

28'. Hojas adultas lampiñas, con glándulas ramificadas en la zona de unión del limbo con el

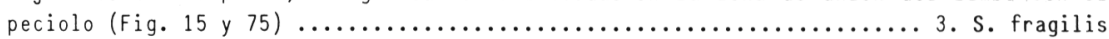

\section{ESTUDIO TAXONOMICO}

I. Subgen. Salix L.

(Typus: S. alba L.)

A. Sect. Amygdalinae W. Koch, Syn. F1. Germ. 664 (1873)

(Lectotypus: S. triandra L.)

1. S. triandra L. subsp. discolor (Koch) Arcangeli, Comp. F1. Ital. $626(1882)$ : (Fig. 16, 29 y 73)

Todo el material recolectado ha de referirse a dicha subespecie, siguiendo los criterios de Rechinger (1964:46); hojas glaucas por el envés y con el pecíolo muy corto en relación con el limbo.

Fitosociologia: Característica del Orden Salicetalia purpureae (Querco-Fageta)

Distribución del material estudiado: Mapa 1 .

B. Sect. Salix L.

( Typus: S. alba L.)

2. S. alba L. Sp. P1. 1021 (1753). (Fig. 6, 36 y 72)

Rechinger (1964:45) y Meikle (1984:43) mantienen distinto criterio a la hora de establecer el rango de los táxones intraespecificos que se pueden reconocer en S. alba $\mathrm{s}$. 1. Así, el primer autor reconoce entre otras: S. alba subsp. vitellina (L.) Arcangeli y S. alba subsp. coerulea (Sm.) Rech. fil., mientras que para Meikle (1984) son simples variedades (var. 
coerulea y var. vitellina). Por nuestras observaciones en el campo, en principio debemos aceptar el primer criterio puesto que aunque conviven en un mismo medio ejemplares pertenecientes a ambos táxones, su presencia se debe a la acción humana.

Fitosociologia: Característica de la Alianza Populion albae (Querco-Fagatea).

2a. subsp. alba

Distribución del material estudiado: Mapa 2 .

2b. subsp. vitellina (L.) Arcangeli, Comp. F1. Ital. 626 ( 1882 )

Distribución del material estudiado: Mapa 2 .

3. S. fragilis L., Sp. P1. 1017 (1753). (Fig. 15, 34 y 75)

Neumann \& Polatschek (1972) consideran que esta especie está ausente de la Península Ibérica siendo reemplazada por $\mathbf{S}$. neotricha. Idéntico criterio mantienen Jalas \& Souminen (1976). $\mathrm{Si}$ aceptamos como buenos caracteres diferenciales para $\mathrm{S}$. fragilis las hojas adultas glabras, con dos glándulas más o menos ramificadas en la unión del limbo con el peciolo, y el ovario y la cápsula sésil o con el pedúnculo más corto que los nectarios, los materiales colectados en los territorios eurosiberianos de la provincia de León y algunos ejemplares dispersos más hacia el sur (Mapa 3) han de referirse incuestionablemente a S. fragilis. Por consiguiente parece lógico pensar que en la Península ibérica S. fragilis se distribuya en los territorios norteños (eurosiberianos) siendo reemplazada en los mediterráneos por $S$. neotricha. Al no encontrar formas de transición entre ambos táxones estimamos que lo más conveniente es mantener la categoria especifica de ambos a pesar de que Vigo (1968) subordinó $\mathrm{S}$. neotricha a $\mathrm{S}$. fragilis (S. fragilis subsp. neotricha).

Fitosociología: Característica de la alianza Populion albae (Querco-Fagetea) .

Distribución del material estudiado: Mapa 3 .

4. S neotricha Görz, Bo1. Soc. Esp. Hist. Nat. 26:385 (1926). (Fig. 76)

La entidad del presente taxon ha sido cuestionada por diversos autores (cf. Vicioso, 1951; Rechinger, 1964) que 10 asimilan a S. $x$ rubens ( $S$. alba $x$ S. fragilis).

Sin embargo Neumann \& Polatschek (1972) reconocen la independencia de $S$. neotricha frente a S. fragilis $y$ S. $x$ rubens. Los materiales que asignamos a $\mathrm{S}$. neotricha presentan unos caracteres claramente diferenciables frente a S. alba, S. fragilis y S. x rubens. Del S. alba y S. fragilis se aleja por presentar las hojas glabrescentes, al igual que $S$. $x$ rubens del que se diferencia por la ausencia de glándulas en el peciolo, asi como por presentar el pedúnculo de la cápsula más largo que los nectarios. El icón que figura en Vicioso (1951:48), 
asignado a S. fragilis creemos que corresponde a S. neotricha si nos basamos en las ilustraciones correspondientes a la flor femenina (5e) y a la rama hojada (5a) donde se aprecia la ausencia de glándulas en la zona de unión del peciolo con el limbo.

Fitosociología: Característica de la alianza Populion albae (Querco-Fagetea).

Distribución del material estudiado: Mapa 4 .

5. S. $x$ rubens Schrank, Baiersch. F1. 1:226 (1798). (S. alba L. x S. fragilis L.). (Fig. 71)

Presenta carácter intermedio entre los parentales, pero siempre con el pedúnculo de la cápsula igual o más corto que el nectario, lo que lo aleja de S. neotricha.

Fitosociologia: Característica de la alianza Populion albae (Querco-Fagetea) .

Distribución del material estudiado: Mapa 5.

C. Nothosect. Amylix form. nov. (=Salix sect. amygdaline W. Koch $\mathrm{x}$ sect. Salix)

6. S. x erytroclados Simonkai, 0est. Bot. Zeitsch. 40:424 (1850). (S. a1ba L. x S. triandra L. subsp. discolor (Koch) Arcangeli). (Fig. 28, 33, 35 y 74 )

Es constante la presencia de flores masculinas con tres estambres, alternando con otras de dos estambres en el mismo amento, carácter que consideramos como muy útil para la identificación de este taxon, pues si bien S. fragilis L. var. decipiens (Hoffm.) Koch también posee flores masculinas con tres estambres (cf. R.D. Meikle, 1984:36), en las hojas adultas de éste aparecen glándulas más o menos ramificadas en la zona de unión del limbo con el peciolo que no existen en $\mathrm{S}$. $\mathbf{x}$ erytroclados.

Fitosociología: Característica de la alianza Populion albae (Querco-Fagetea).

Distribución del material estudiado: Mapa 6.

II. Subgen. Vetrix (Dum.) Dum., Bull. Soc. Bot. Belg. 1:141 $(1862)$. (Lectotypus: S. caprea L.)

A. Sect. Vetrix Dum., Bijdr. Natuurk. Wetensch. 1, 1:55 (1825) ( Typus: S. caprea L.) 
7. S. caprea L., Sp. P1. 1020 (1753). (Fig. 17, 41 y 63)

Fitosociologia: Característica de Querco-Fagetea.

Distribución del material estudiado: Mapa 7 .

8. S. salvifolia Brot., F1. Lusit. 1:29 (1804). (Fig. 23, 42 y 67 )

Fitosociología: Caracteristica de la alianza Salicion salvifoliae (Querco-Fagetea).

Distribución del material estudiado. Mapa 8 .

9. S. atrocinerea Brot., F1. Lusit. 1:31 (1804). (Fig. 20, 44 y 64 )

A pesar de las razones expuestas por Meikle (1984) que lo considera subordinado a S. cinerea (S. cinerea L. subsp. oleifolia (Gaudin) Macreight, Manual of British Botany, 212 . $1873=$ S. cinerea L. subsp. atrocinerea (Brot.) Silva et Sobrinho $(1950)=$ S.cinerea L. var. oleifolia Gaudin, Flora Helvetica, 6:242, 1830) por su área de distribución, y caracteres diferenciales pensamos que es más oportuno mantenerlo en el rango especifico como propone Rechinger (1964).

Fitosociologia: Caracteristica de la Clase Querco-Fagetea.

Distribución del material estudiado: Mapa 9 .

10. S. cantabrica Rech. fil., Osterr. Bot. Zeitschr. $109: 374$ (1962). (Fig. 8 y 57)

Sauce de distribución orocantábrica que penetra en el mundo mediterráneo en los territorios más septentrionales del castellano-cantábrico, leonés y orensano-sanabriense, existiendo en este último sector una interesente disyunción en los valles del Eria y Duerna, sitos en la fachada suroriental de los Montes Aquilanos y de la Sierra de Cabrera.

Fitosociologia: Característica de la asociación Salicetum cantabricum (Salicion triandro-neotrichae, Salicetalia purpureae, Querco-Fagetea).

Distribución del material estudiado: Mapa 10 .

11. S. X secalliana Pau \& Vicioso in Pau, Bol. Soc. Iber. Ć. Nat. 18:83 (1919). (S. atrocinerea Brot. x S. salvifolia Brot.). (Fig. 25)

Fitosociologia: Caracteristica de la alianza Salicion salvifoliae (Salicetalia salvifoliae, Querco-Fagetea).

Distribución del material estudiado: Mapa 11. 
12. S. x quercifolia Sennen, Bu11. Soc. Bot. France 74:400

(1927) (S. atrocinerea Brot. x S. caprea L.). (Fig. 21)

Fitosociologia: Característica de la Clase Querco-Fagetea.

Distribución del material estudiado: Mapa 12.

13. S. x expectata Rivas-Martínez, T.E. Díaz, J.A. Prieto, J. Loidi \& A. Penas nothosp. nov. (S. atrocinerea Brot. $x$ S. cantabrica Rech. fil.). (Fig. 9, 38 y 58 )

Diagnosis: Difert a $S$. atrocinerea quia glaucam adultorum foliorum faciem adprehenso-sericeis pilis exhibet et a $S$. cantabrica quia subglabrescentem faciem exhibet.

Holotypus: San Vicente del Condado $\left(\sigma^{\circ}\right), 880 \mathrm{~m}$, 30Tuno2, 10-V-85, T.E. Díaz \& al., LEB 29747.

Arbusto con ramas jóvenes angulosas, cubiertas de un denso tomento blanquecino, las adultas pruinosas, ligeramente pubescentes. Yemas aovadas, agudas, inicialmente tomentosas y finalmente pubescentes. Hojas alternas, de oblongo-lanceoladas a trasovadas, cuneadas en la base o redondeadas, con el ápice más o menos agudo. Haz con nervios no muy marcados, de jóvenes con pubescencia de pelos aplicados y retorcidos, perdiendo paulatinamente la pilosidad desde el ápice, en ocasiones con pelos amarillento-rojizos, mezclados con pelos blancos. Envés glauco con pelos adpresos, brillantes; a veces ralos, y en ocasiones con algún pelo rojizo. Nervio central resaltado, asi como el inicio de los laterales. Estipulas de linear-lanceoladas a reniformes. Amentos alternos, coetáneos o no. Los masculinos pedunculados, bracteados en su base, cilindricos, de 1,5-3 cm de longitud. Flores masculinas con escamas discoloras cubiertas de largos y sedosos pelos blanquecinos-brillantes; un nectario corto y dos estambres con filamentos libres hasta la base y pelosos en su $\frac{1}{2}$ inferior. Amentos femeninos de $1,5-8 \mathrm{~cm}$, cilindricos. Flores femeninas con escamas discoloras cubiertas de largos pelos blanquecinos-brillantes; un nectario corto; ovario y cápsula pedunculada y densamente cubierta de pelos sedosos-brillantes, blanquecinos, o bien con una pubescencia rala. Estilo corto y estigmas bilobulados.

Fitosociologia: Característica de la asociación Salicetum cantabricum (Salicion triandro-neotrichae, Salicetalia purpureae, Querco-Fagetea).

Distribución del material estudiado: Mapa 13 .

14. S. $x$ coenocarpetana Rivas-Martínez, T.E. Diaz, J.A. Prieto, J. Loidi \& A. Penas, Veg. Alt. Mont. Cantábrica: Los Picos de Europa: $283(1984)$. (S. cantabrica Rech. fil. x S. salvifolia Brot.). (Fig. 14)

Fitosociologia: Característica de la alianza Salicion triandro-neotrichae (Salicetalia purpureae, Querco-Fagetea).

Distribución del material estudiado: Mapa 14 . 
15. S. x pormensis T.E. Díaz \& F. Llamas, nothosp. nov. (S. cantabrica Rech. fil x S. caprea L.). (Fig. 13)

Diagnosis: Difert a S. cantabrica maiorum mensusrarum foliis ellipticis vel lanceolato-ellipticis, summo gradu recurvato et stipulis semireniformibus. Difert a S. caprea quia sericea pila et facie et foliorum tergo adprehensa habet.

Holotypus: Puebla de Li11o, $1280 \mathrm{~m}, 30 \mathrm{TUN} 16, \mathrm{~F}$. L1amas, LEB 30583. Isotypus: LEB 30584 .

Arbol con ramas jóvenes tomentoso brillantes, las del año anterior estriadas menos densamente tomentosas, yemas sedoso-sericeas. Hojas alternas elipticas o lanceolado-elípticas redondeadas en la base o ligeramente atenuadas, terminadas en punta por lo común curvada, a veces obtusa, de 3-10 x 1,5-3,5 cm, con el margen de entero a ondulado-dentado de jóvenes sedoso-argénteas y las adultas con el envés brillante cubierto densamente de pelos adpreso-sericeos mezclados con algunos pelos retorcidos, con nervio central ligeramente prominente y los laterales más o menos realzados. Haz verde-grisáceo cubierto de un tomento, a veces ralo, de pelos adpreso-seríceos, mucho más denso sobre el nervio central y laterales. Peciolo de 3-14 mm densamente tomentoso con estipulas grandes semi-reniformes, dentadas y densamente tomentosas, caedizas.

Fitosociologia: Caracteristica de la alianza Salicion triandroneotrichae (Salicetalia purpureae, Querco-Fagetea).

Distribución del material estudiado: Mapa 15 .

B. Sect. Vimen Dum., Bijdr. Natuurk. Wetensch. 1, 1:56 (1825). (Lectotypus: S. viminalis L.)

16. S. viminalis L., Sp. P1., 1021 (1753). (Fig. 5, 37 y $56)$

Aunque no muy frecuentemente en el territorio, en épocas pasadas 1o debió ser, debido a su empleo en labores de cestería. Parte del material recogido pertenece a la var. angustissima Cosson \& Germain caracterizado por sus hojas estrechamente 1 ineares.

Distribución del material estudiado: Mapa 16 .

C. Sect. canae A. Kerner, Nied.-Oesterr. 222 (1860)

(Lectotypus: S. elaeagnos Scop.)

17. S. elaeagnos Scop. subsp. angustifolia (Cariot) Rech. fil., Osterr. Bot. Zeitschr. 104:314 (1957). (Fig.18, 45 y $70)$

Fitosociologia: Característica de la alianza Salicion triandroneotrichae (Salicetalia purpureae, Querco-Fagetea). 
Distribución del material estudiado: Mapa 17 .

D. Sect. Helix Dum. 1. c. 56 (1825)

(Lectotypus: S. purpurea L.)

18. S. purpurea L. subsp. lambertiana ( $\mathrm{Sm}$.) A. Neumann ex Rech. fil., Osterr. Bot. Zeitschr. 110:34 (1963). (Fig. 1, 26 y 55 )

Fitosociologia: Característica del Orden Salicetalia purpureae (Querco-Fagetea).

Distribución del material estudiado: Mapa 18 .

E. Nothosect. Vimetrix form. nov. (= Salix sect. Vetrix (Dim.) Dum. $x$ sect. Vimen Dum.)

19. S. x stipularis Sm. in Sowerby, Engl. Bot. 17:t. 1214 (1803) (S. atrocinerea Brot. x S. viminalis L.). (Fig. 10)

Los materiales colectados presentan caracteres tanto de $\mathrm{S}$. atrocinerea como de $\mathrm{S}$. viminalis, diferenciándose del primero por presentar hojas adultas con pelos seríceos por el envés y alejándose del segundo por la morfología foliar (lanceoladoovales), así como por tener el ovario y la cápsula netamente pedunculada. Rechinger (1964:53) al referirse a S. x stipularis señala que "posiblemente corresponde a $S$. atrocinerea $x \quad S$. viminalis". Por esta causa y hasta conocer el tipo de S. $x$ stipularis denominamos asi los materiales recogidos.

Fitosociología: Caracteristica de la Clase Querco-Fagetea.

Distribución del material estudiado: Mapa 19.

20. S. x viridifolia T.E. Díaz \& A. Penas nothosp. nov. (S. salvifolia Brot. $x$ S. viminalis L.). (Fig. 12,40 y 62 )

Diagnosis: Difert a S. salvifolia quia in tergo adulta fulgentis tomenti sericeis pilis applicatis constituti folia exhibet. Difert a $S$. viminalis quia in adultorum foliorum facie flexa pilá et capsulam et ovarium nitide pedunculata exhibet.

Holotypus: Castrofuerte ( $\left.\mathrm{o}^{*}\right), 780 \mathrm{~m}, 30$ TTM97, 20-IV-85, T.E. Díaz \& al., LEB 30512. Isotypus: Bis ( $\left.\sigma^{*}\right)$, LEB 30513.

Arbol o arbusto con ramas juveniles tomentosas, las adultas casi glabras. Yemas aovado-obtusas, tomentosas. Hojas alternas, lanceolado-oblongas, cuneadas en la base, agudas en el ápice, con el margen engrosado entero o denticulado-glanduloso; haz verde claro, cubierto de un tomento ralo de pelos retorcidos; envés cubierto de un tomento brillante constituido por pelos aplicados mezclados con otros retorcidos, con el nervio axial ligeramente resaltado. Peciolo pubescente, ligeramente ensanchado en la base. Estípulas caedizas. Amentos coetáneos, los masculinos ligeramente pedunculados, bracteados en la base, de 
2-3 cm de longitud, con el eje lanoso. Flores masculinas con escamas discoloras, con el ápice truncado y púrpura-negruzco, rosado en la base, densamente cubiertas con pelos blanquecinos. 1 nectario. 2 estambres libres hasta la base, con los filamentos pelosos cerca de la base. Anteras amarillas. Amentos femeninos ligeramente pedunculados y bracteados en la base, con eje lanoso. Flores femeninas con escamas discoloras o concoloras. 1 nectario amarillento rectangular; ovario con el pedúnculo $2-3$ veces más largo que el nectario, cápsula cubierta de pelos blanquecinos. Estilo largo y estigmas bífidos.

Fitosociologia: Característica de la Clase Querco-Fagetea.

Distribución del material estudiado: Mapa 20 .

F. Nothosect. Catrix form. nov. (Salix sect. vetrix (Dum.) Dum. $x$ sect. Canae A. Kerner)

21. S. $x$ pseudosalvifolia T.E. Diaz \& E. Puente nothosp. nov. (S. elaeagnos Scop. subsp. angustifolia (Cariot) Rech. fil. x S. salvifolia Brot.). (Fig. 24, 43, 52, 53, 54, 68 у 69)

Diagnosis: Difert a S. Elaeagnos subsp. angustifolia adultis foliis lineari-lanceolatis facie flexorum pilorum tomento vestita. Ovario et capsula vel tota vel partim villosa et nitide pedunculata. Difert a $S$. salvifolia adultis foliis tergo cano-tomentosis et staminibus fibris in $1 / 3-1 / 2$ inferiore consolatis.

Holotypus: Mansilla de las Mulas (q), $890 \mathrm{~m}, 30 \mathrm{TUN} 00,24-\mathrm{V}-85$, T.E. Diaz \& a1., LEB 30445. Isotypus: Bis (q), LEB 30446; Bis $(q)$, LEB 30447 .

Arbusto densamente ramificado con ramas largas, de corteza pardo-grisácea o pardo-violácea. Ramas juveniles rojizas o amarillo-grisáceas, tomentosas quedando glabras en el segundo año. Yémas pardo-rojizas, aovadas, obtusas, tomentosas. Hojas alternas, linear-lanceoladas, de (10)40-90 x (3)7-15 mm, ligeramente cuneadas en la base y agudas en el ápice, con el margen generalmente dentado-glanduloso y revuelto en las hojas jóvenes; márgenes paralelos al menos en las hojas adultas; haz verde oscuro, mate, cubierto por un ralo tomento de pelos retorcidos; envés cano-tomentoso, formado por fieltro de pelos espesos; nervio central bastante realzado. Peciolo corto, ensanchado en la base y tomentoso; estípulas muy pequeñas. Amentos coetáneos. Los masculinos bracteolados, 1 igeramente curvados y de $1,5-2,5 \mathrm{~cm}$ de longitud; flores masculinas con escamas concólores o discólores, cubiertas de largos pelos blanquecinos; 1 nectario; 2 estambres con los filamentos soldados en el $1 / 3$ ó $1 / 2$ inferior (raramente con los filamentos libres o bien con 1 ó 3 estambres). Amentos femeninos ligeramente pedunculados y bracteados en la base, de $1,8-3,5 \mathrm{~cm}$ de longitud, cilindricos y arqueado-colgantes con eje peloso; Flores femeninas con escamas concoloras o discoloras, pelosas; 1 nectario amarillo de la misma longitud o más corto que el pedúnculo del ovario o cápsula; ésta ligeramente pubescente en el ápice (raramente totalmente pubescente, pero con pilosidad 
decreciente desde el ápice a la base o bien solamente glabra en el pedúnculo); estilo alargado con estigmas bífidos.

Fitosociologia: Caracteristica territorial de la asociación Salicetum angustifolio-salvifoliae (Salicion salvifoliae, Salicetalia purpureae, Querco-Fagetea).

Distribución del material estudiado: Mapa 21.

G. Nothosect. Hetrix form. nov. (Salix sect. Vetrix (Dum.) Dum. $x$ sect. Helix Dum.)

22. S. x matritensis Pau \& C. Vicioso in C. Vicioso, Anal. Jard. Bot. Madrid 7:19 (1946). (S. purpurea L. subsp. lambertiana (Sm.) A. Neumann ex Rech. fil. x S. salvifolia Brot.). (Fig. 4)

Fitosociologia: Característica de la alianza Salicion salvifoliae (Salicetalia purpureae, Querco-Fagetea).

Distribución del material estudiado: Mapa 22 .

23. S. x viciosorum Sennen \& Pau in Senenn, P1. Esp. exs. 1562 (1912): (S. atrocinerea Brot. x S. purpurea L.). (Fig. 3).

Fitosociologia: Caracteristica del Orden Salicetalia purpureae (Querco-Fagetea) .

Distribución del material estudiado: Mapa 23.

H. Nothosect. Camen form. nov. (Salix sect. Canae A. Kerner $x$ sect. Vimen Dum.)

24. S. longissima T.E. Díaz \& J. Andrés nothosp. nov. (S. elaeagnos Scop. subsp. angustifolia (Cariot) Rech. fil. x S. viminalis L.). (Fig. 19)

Diagnosis: Difert a S. elaeagnos subsp. angustifolia quia adulta folia lineari-lanceolata clare viridi facie exhibet. Difert a S. viminalis quia in foliorum tergo villi copiam tomentoso-aracnoideam exhibet.

Holotypus: La Martina, $490 \mathrm{~m}, 29 \mathrm{TPH} 91,16-\mathrm{VI}-85$, T.E. Diaz \& al., LEB 29538. Isotypus: Bis, LEB 29539; Bis, LEB 30605.

Arbol o arbusto con ramas jóvenes pardo-rojizas cubiertas de un tomento blanco aracnoideo; las adultas glabras con la corteza estriada longitudinalmente. Yemas oblongo-lanceoladas, obtusas, de jóvenes pubescentes. Hojas a1ternas, lanceoladolineares, más de cinco veces tan largas como anchas, atenuadocuneiformes en su base, acuminadas en su ápice, con el margen engrosado, entero o denticulado-glanduloso; haz verde claro, poco lustroso, glabro o aracnoideo-pubescente; envés lustroso, 
tomentoso-aracnoideo con el nervio axial muy prominente. Peciolo corto, dilatado en la base y pubescente. Estipulas caedizas, linear-lanceoladas, enteras o denticulado-glandulosas. No se conocen los amentos.

Fitosociologia: Característica de la alianza Salicion triandroneotrichae (Salicetalia purpureae, Querco-Fagetea).

Distribución del material estudiado: Mapa 24 .

I. Notosect. Calix form. nov. (Salix sect. Canae A. Kerner x sect. Helix Dum.)

25. S. $x$ pseudoelaeagnos T.E. Diaz \& F. Llamas nothosp. nov. (S. elaeagnos Scop. subsp. angustifolia (Cariot) Rech. fil. x S. purpurea L. subsp. lambertiana (Sm.) A. Neumann ex Rech. fil.) (Fig. 2)

Diagnosis: Difert a S. elaeagnos subsp. angustifolia quia aliquot amentos et opposita folia exhibet. Folia lanceolatolinearia sunt. Difert a S. purpurea subsp. lambertiana foliis quae tergum araneo raro tomento opertum et crasum in centrico nervo qui prominens est habent, et staminibus que fibras partim consolidatas exhibent.

Holotypus: Cuadros $\left(\sigma^{\prime}\right), 910 \mathrm{~m}, 30 \mathrm{TTN} 83,26-$ IV-85, T.E. Díaz \& a1., LEB 30505. Isotypus: Bis ( ó), LEB 30506; Bis ( o $\left.\sigma^{\prime}\right)$, LEB 30507 .

Arbusto con ramas jovenes pubescentes, las del año anterior glabras o casi; yemas glabrescentes. Hojas en su mayoría alternas, sólo algunas opuestas, lanceoladas, de 25-70 x 4-10 $\mathrm{mm}$, con el margen generalmente revuelto, aserrado-glanduloso, de jóvenes sedoso-glabrescente en ambas caras, de adultas pubescentes, verde en el haz y con el envés glauco, cubierto de tomento aracnoideo ralo. Amentos alternos en su mayoria con algunos opuestos; los masculinos coetáneos y bracteados en la base; flores masculinas con escamas discólores con el ápice negruzco o rosado, lanceolado-oblongas, densamente pelosas; 1 nectario; 2 estambres con los filamentos soldados en la mitad inferior o bien hasta cerca del ápice, con la base peloso-1anosa; anteras rojizas o amarillentas. Amentos femeninos no conocidos.

Fitosociologia: Caracteristica de la alianza Salicion triandro-neotrichae (Salicetalia purpureae, Querco-Fagetea).

Distribución del material estudiado: Mapa 25.

III.Nothosubgen. Velix form. nov. (Salix subgen. Salix x subgen. Vetrix Dumort.)

A. Nothosect. Amytrix form. nov. (Salix sect. Amygdalinae W. Koch $x$ sect. Vetrix (Dumort.) Dumort. 
26. S. x multidentata T.E. Diaz \& F. Llamas nothosp. nov . (S. atrocinerea Brot. $x$ S. triandra L. subsp. discolor (Koch.) Arcangeli.). (Fig. 22, 65 y 66)

Diagnosis: Difert a $S$. atrocinerea quia margines foliorum serrato-dentatas et glandulosas exhibet. Difert a $S$. triandra subsp. discolor quia ferruginea pila in utrisque folii partibus exhibet et quia ovarium tomentosum vel glabrescente est.

Holotypus: Hospital de Orbigo (o), $780 \mathrm{~m}, 30 \mathrm{TTN} 60,7-\mathrm{V}-85$, T.E. Diaz \& a1., LEB 30532. Isotypus: Bis (q), LEB 30533.

Arbusto con ramas púrpuras o verdosas, las del año tomentosas. Hojas alternas, aovado-espatuladas, más o menos agudas en el ápice, con un tinte rojo-púrpura y tomentosas por ambas caras de jóvenes; de adultas con el margen aserrado-dentado con los dientes glandulosos (raramente entero); haz reticulado verde oscuro, glabro o glabrescente con pelos rojizos o amarillentos; envés glauco con una ligera pubescencia de pelos rojizos o blanquecinos, quedando finalmente casi glabro, con nervios muy resaltados. Estipulas grandes, arriñonadas, dentado-glandulosas, glabras o ligeramente pubescentes. Amentos femeninos cortamente pedunculados, bracteados en su base con el eje lanoso. Flor femenina con escamas concoloras o discoloras, negruzcas en el ápice, espatuladas, con el ápice truncadoredondeadas, densamente cubiertas con pelos lanosos largos, 1 nectario. Ovario pedunculado, hinchado en el tercio inferior, cubierto de un tomento corto, a veces glabrescente parcialmente. Estilo corto o nulo, con estigmas bilobulados. Amentos masculinos no conocidos.

Fitosociologia: Caracteristica del orden Salicetalia purpureae (Querco-Fagetea).

Distribución del material estudiado: Mapa 26.

27. S. $x$ rijosa Rivas-Martínez, T.E. Diaz, J.A.F. Prieto, J. Loidi \& A. Penas nothosp. nov. (S. cantabrica Rech. fil. $x$ S. triandra L. subsp. discolor (Koch.) Arcangeli. (Fig. $11,27,30,31,32,39,47,48,49,50,51,59,60$ у 61 )

Diagnosis: Difert a S. cantabrica quia marginem foliorum adultorum auctam et serrato-glandulosam obscure viridi et fulgenti facie, copiosis sericeis applicatis ac vetustis pilis, exhibet. Flores viriles cum 1,2 vel 3 staminibus 1 iberarum aut totum aut partim consolidatarum fibrarum sunt. Difert a $S$. triandra subsp. discolor quia tergum adultorum foliorum copiosis adpreso-sericeis pilis et ovarium et capsulam dense tomentosa exhibet.

Holotypus: Robles de la Valcueva (o), $970 \mathrm{~m}, 30 \mathrm{TTN} 94,17-\mathrm{V}-85$, T.E. Diaz \& a1., LEB 30494. Isotypus: Bis (q), LEB 30495; Bis (q), LEB 30496 .

Arbusto de hasta $5 \mathrm{~m}$, con ramas viejas pardo-verdosas con corteza fisurada, ramas del año de color púrpura o verde grisáceo, de denso a ligeramente tomentosas-aracnoideas, quedando glabras al hacerse adultas. Yemas pubescentes a tomentosas, más o menos amarillentas. Hojas alternas de aovado-1anceoladas a elipsoides, con los extremos atenuados, ápice agudo recurvado hacia abajo, margen aserrado-glanduloso, cartilagi- 
noso-engrosado; haz verde oscuro brillante con mezcla de pelos sedosos aplicados (y amarillento-rojizos) que generalmente se van perdiendo paulatinamente desde el ápice en las hojas adultas; envés glauco, cubierto de pelos adpreso-seríceos, con el nervio central resaltado, asi como el inicio de los laterales, los cuales están unidos por anastómosis a nervios terciarios. Peciolos canaliculados en la cara superior, cortos, densamente pubescentes y glandulosos en el ápice. Estípulas pequeñas o bien grandes arriñonadas y dentado-glandulosas. Amentos coetáneos, los masculinos cortos y bracteados. Flores masculinas con escamas truncadas o redondeadas en el ápice, bicoloras, recubiertas de largos pelos blancos; 1 nectario más corto que la escama; 1 estambre con dos anteras con e1 filamento ampliamente hinchado en el ápice y provisto de largos pelos blancos desde la base al ápice (raramente con 2 ó 3 estambres con los filamentos libres o parcialmente soldados; en algunos individuos se observan aberraciones como el reemplazamiento de una antera o una teca por un ovario). Amentos femeninos pedunculados, bracteados en la base. Flores femeninas con escamas bicoloras, cubiertas de largos pelos; 1 nectario corto, truncado y amarillento; ovario y cápsula con el pedúnculo de la misma longitud, igual o más corto que la escama, densamente cubierto de pelos brillantes. Estilo nulo, corto o largo. Estigmas bilobulados. (Se han visto individuos con aberraciones en los que salen 3 ovarios de la misma escama).

Fitosociologia: Caracteristica de la alianza Salicion triandroneotrichae (Salicetalia purpureae, Querco-Fagetea).

Distribución del material estudiado: Mapa 27.

\section{AGRADECIMIENTOS}

Agrradecemos a D. Benito del Campo, Catedrático de Latín, la traducción latina de las diagnosis.

\section{BIBLIOGRAFIA}

ARGUELLES, J.M.; DELGADO, J. \& LAINZ, M. -1984- Contribuciones al conocimiento de la flora de Asturias. I. Bol. Cien. Nat. I.D.E.A. $33: 3-14$

DIAZ, T.E.; ANDRES, J.; LLAMAS, F.; HERRERO, L. \& FERNANDEZ, M.D. -1986Datos sobre la vegetación de las olmedas y alisedas mediterráneas de la provincia de León (NW de España). Secr. Publ. Univ. La Laguna. Ser. Informes no 19 (en prensa).

DIAZ, T.E. \& PENAS, A. -1986- Estudio de las saucedas mediterráneas de la provincia de León. Secr. Publ. Univ. La Laguna. Ser. Informes no 19 (en prensa).

GORZ, R. -1926- Beiträge zir kenndnis der Salix - flora Spaniens. Bol. Soc. Esp. Hist. Nat. 26:385-388.

GORZ, R. -1930- Les saules de Catalogne. Cavanillesia 2:97-158.

JALAS, J. \& SOUMINEN, J. -1976- Atlas Florae Europeae. Vol. 3. Helsinki.

MEIKLE, R.D. -1984- Willows and Poplars of Great Britain and Ireland. Bot. Soc. Brit. Isles. London.

NEUMANN, A. \& POLATSCHEK, A. -1972- Cytotaxonomischer Beitrag zur Gattung Salix. Ann. Naturh. Mus. (Wien) 76:619-633. 
PUENTE, E. -1985- Flora y Vegetación de la Cuenca Alta del ríó Sil (León). Memoria Doctoral. Univ. de León (inéd.).

RECHINGER, F.H. -1957- Salix, in HEGI, G. Illustrierte Flora von Mittel-Europa, 2a ed. 3:44-135. Munich.

RECHINGER, K.H. -1964- in TUTIN, T.G. \& al. Salix L. in Flora Europaea. $1: 43-54$. Cambridge.

RIVAS-MARTINEZ, S.; DIAZ, T.E.; F. PRIETO, J.A.; LOIDI, J. \& PENAS, A. -1984- La Vegetación de la alta montaña cantábrica. Los Picos de Europa. Ed. Leonesas. León.

SKVORTSOV, A. -1968- Nomenclatura et Typificatio generis Salix L. subgenerum, sectionum, subsectionum and floram URSS pertinentium. Acord. Sci. URSS, Nov. Syst. Plant. vasc. :62-72. VICIOSO, C. -1951- Salicáceas de España. Inst. For. Invest. Agr. Madrid.

VIGO, J. -1968- La vegetació del Massís de Penyagolosa. Inst. Est. Catalans. Barcelona. 


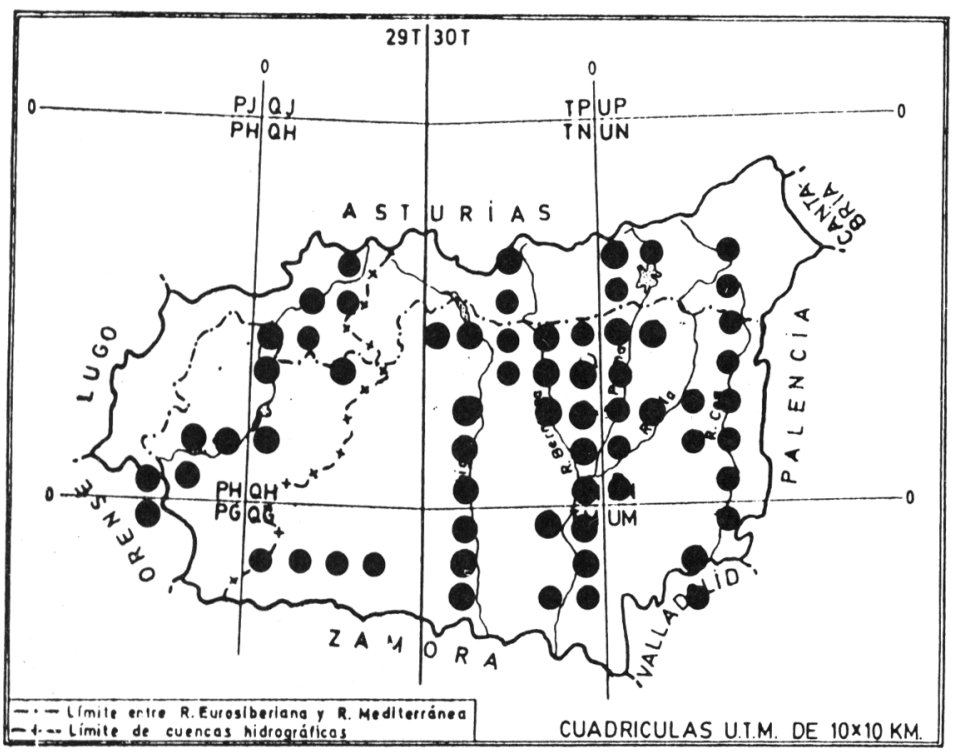

Mapa 1.- Distribución de S. triandra subsp. discolor.

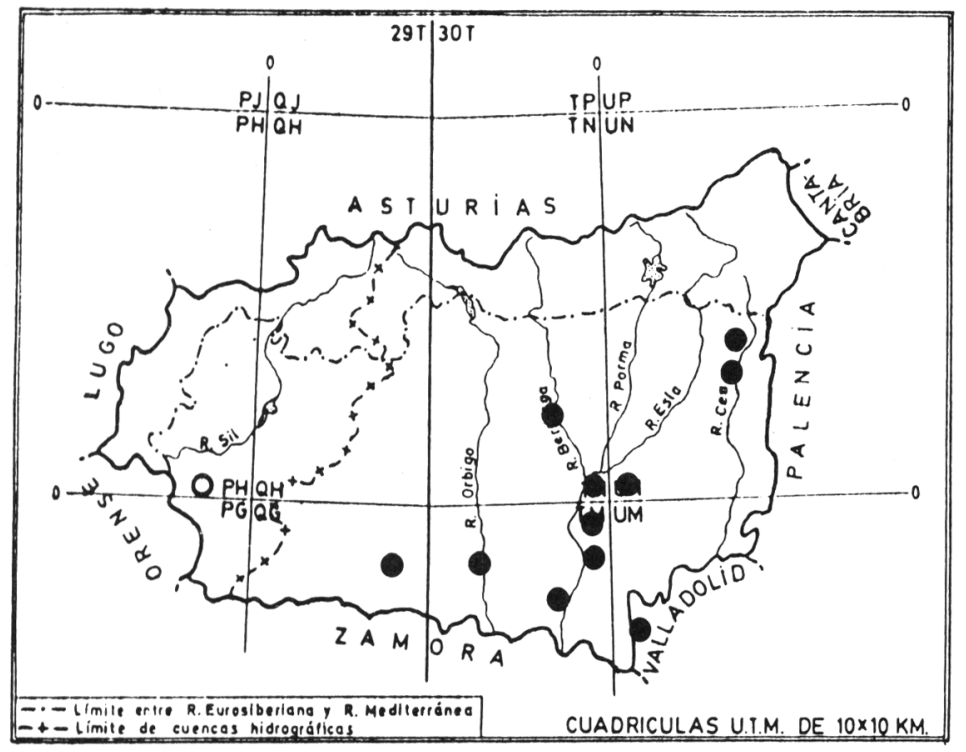

Mapa 2.- Distribución de S. alba. 


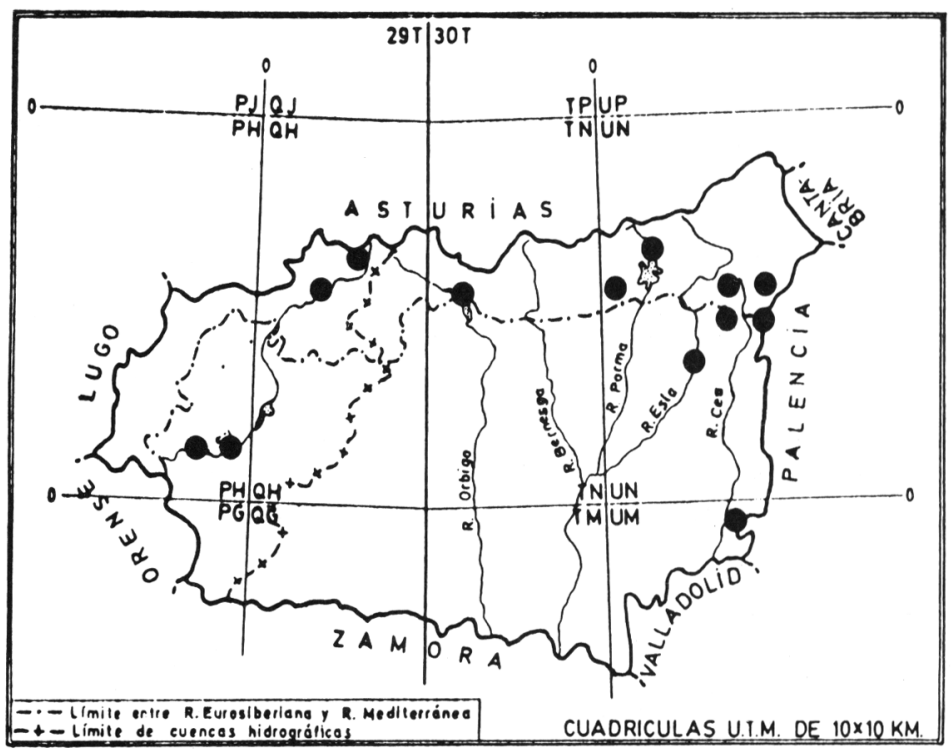

Mapa 3.-Distribución de S. fragilis.

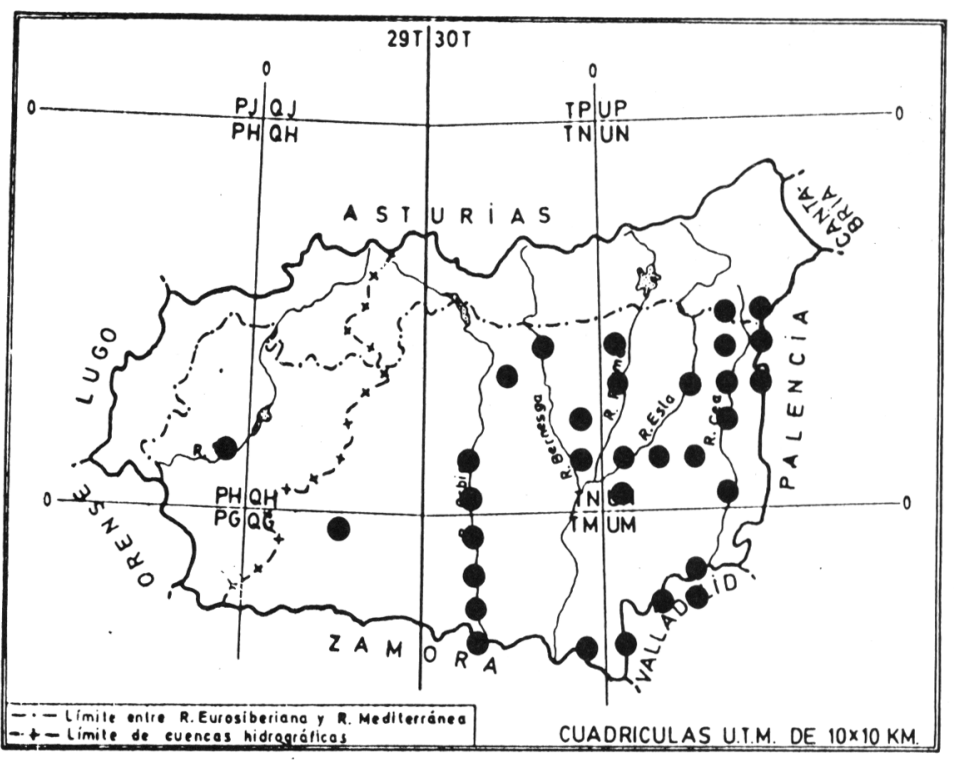

Mapa 4.- Distribución de S. neotricha. 


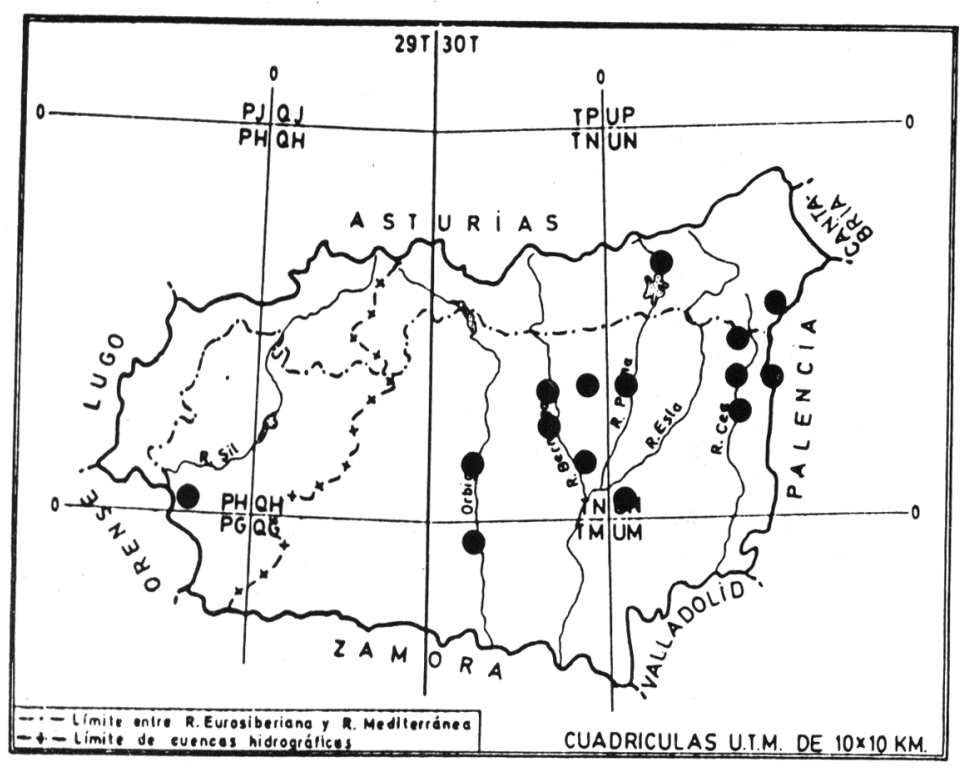

Mada 5.- Distribución de S. x rubens.

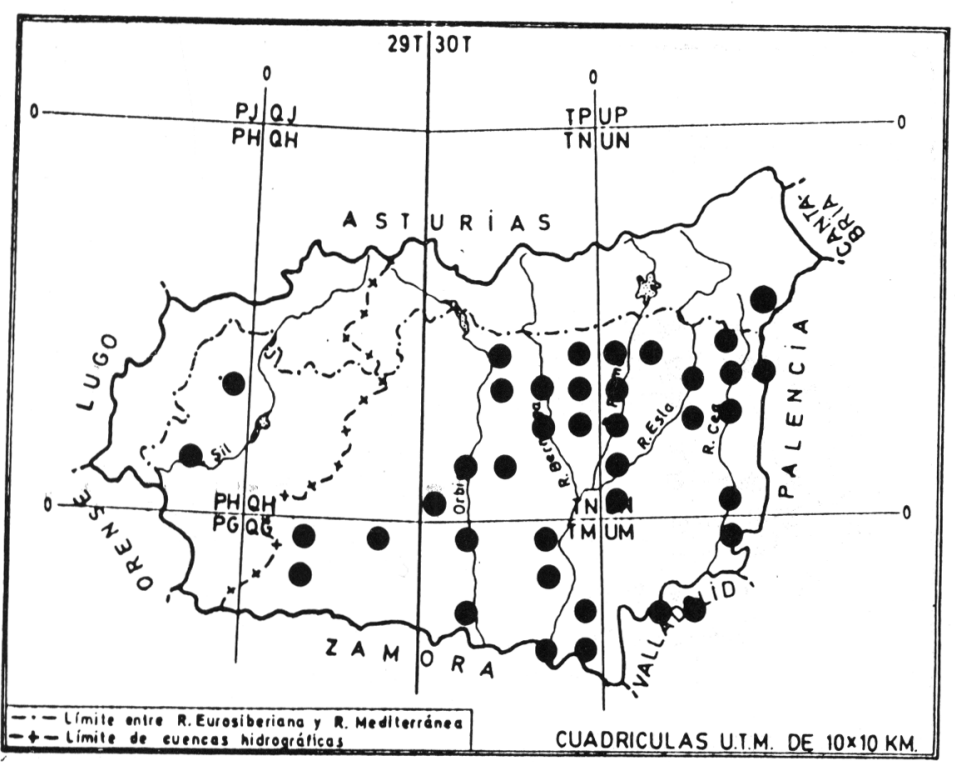

Mapa 6.- Distribución de S. x erytroclados. 


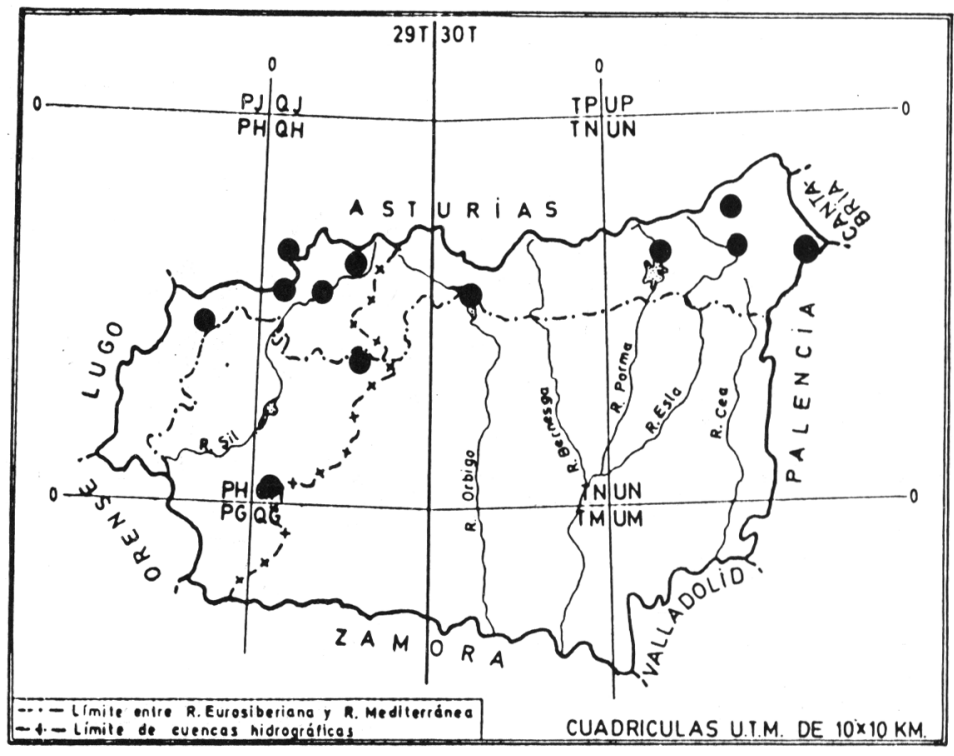

Mapa 7 - Distrbución de S. caprea.

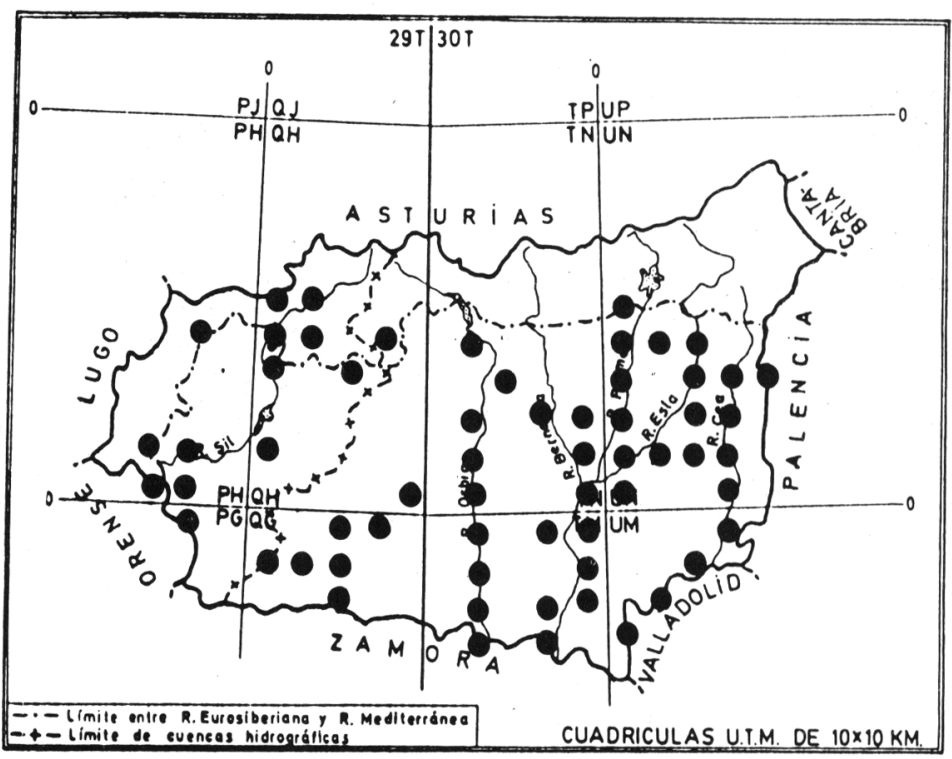

Mapa 8.- Distribución de S. salvifolia. 


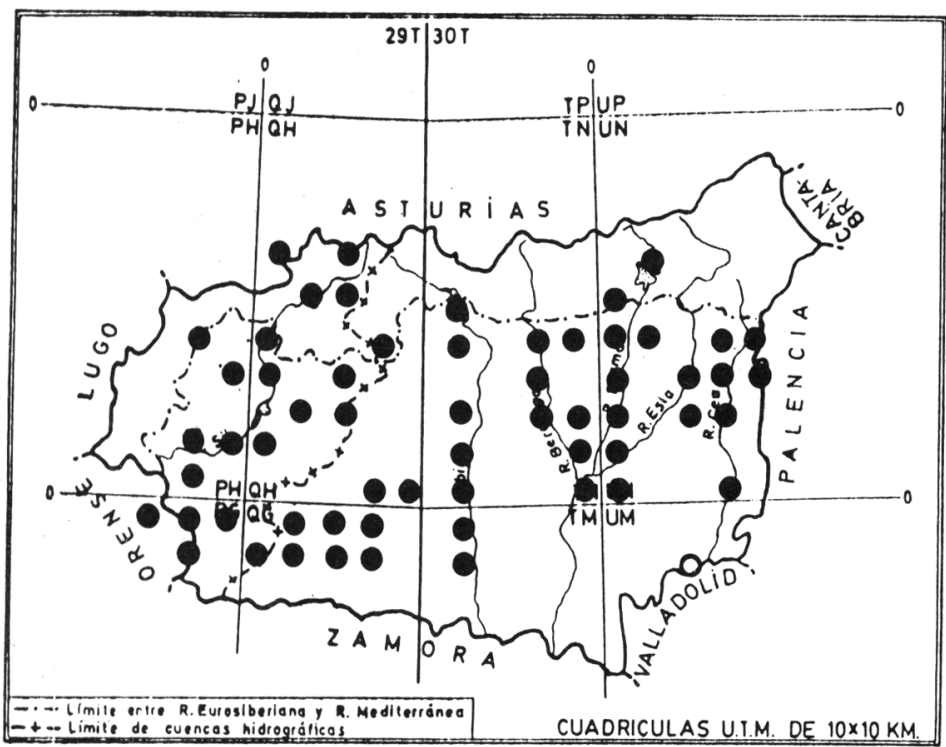

Mapa 9.- Distribución de S. atrocinerea

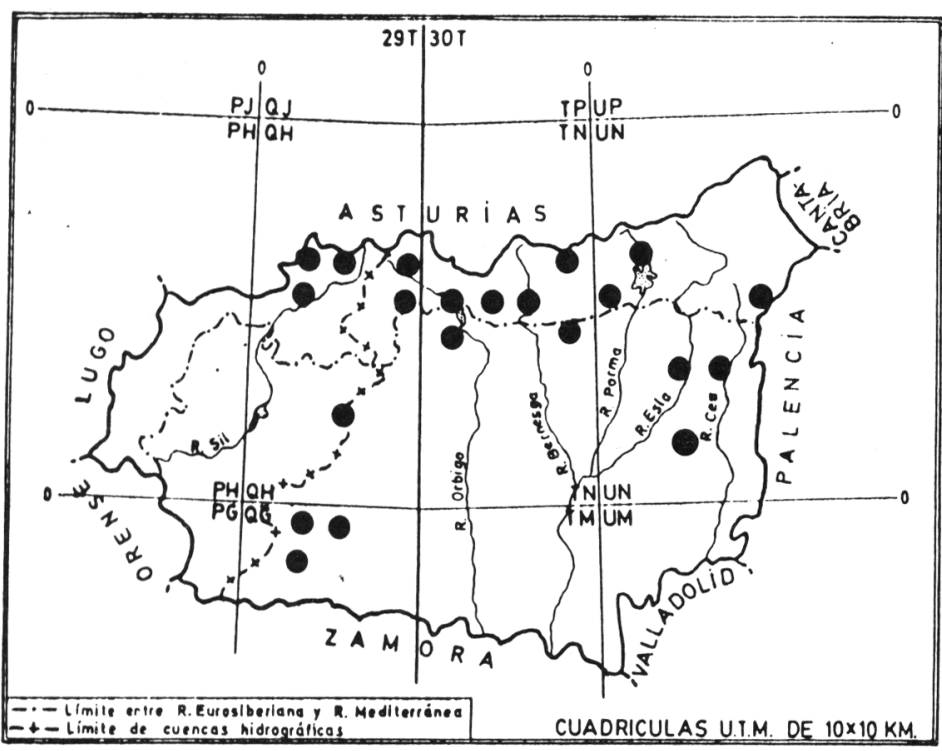

Mapa 10.- Distribución de S. cantabrica. 


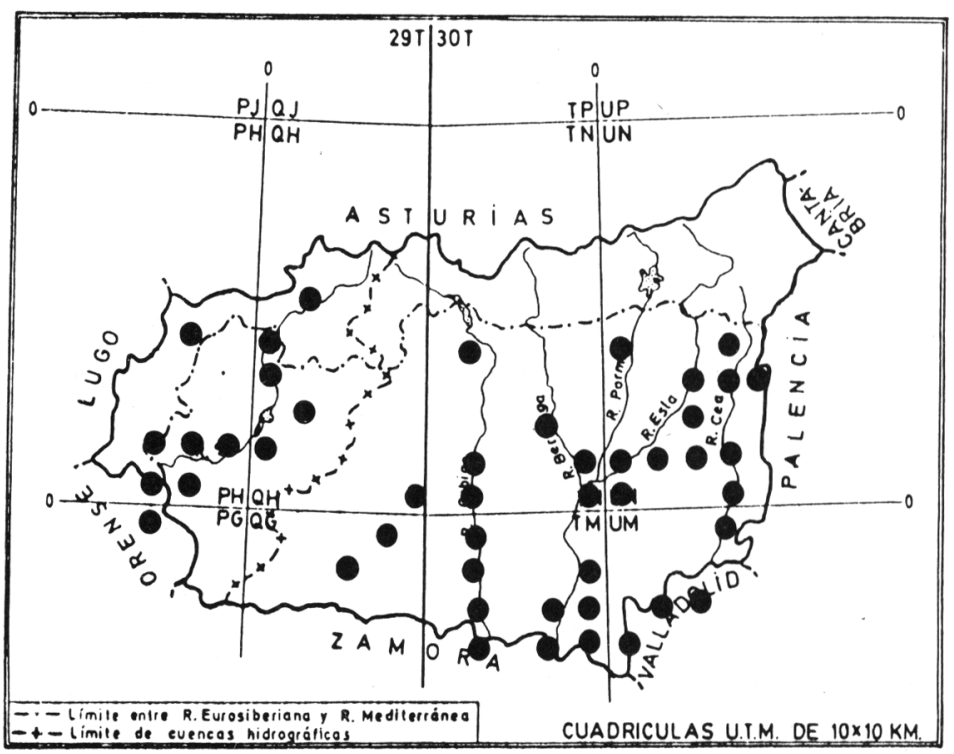

Mapa 11.- Distribución de S. x secalliana.

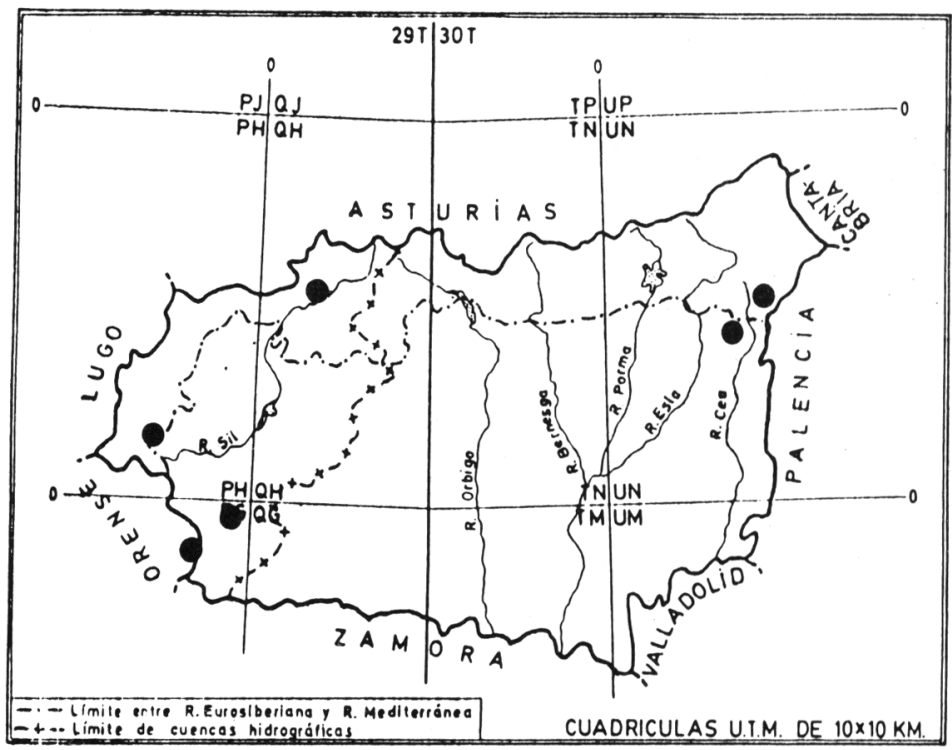

Mapa 12.- Distribución de S. x quercifolia. 


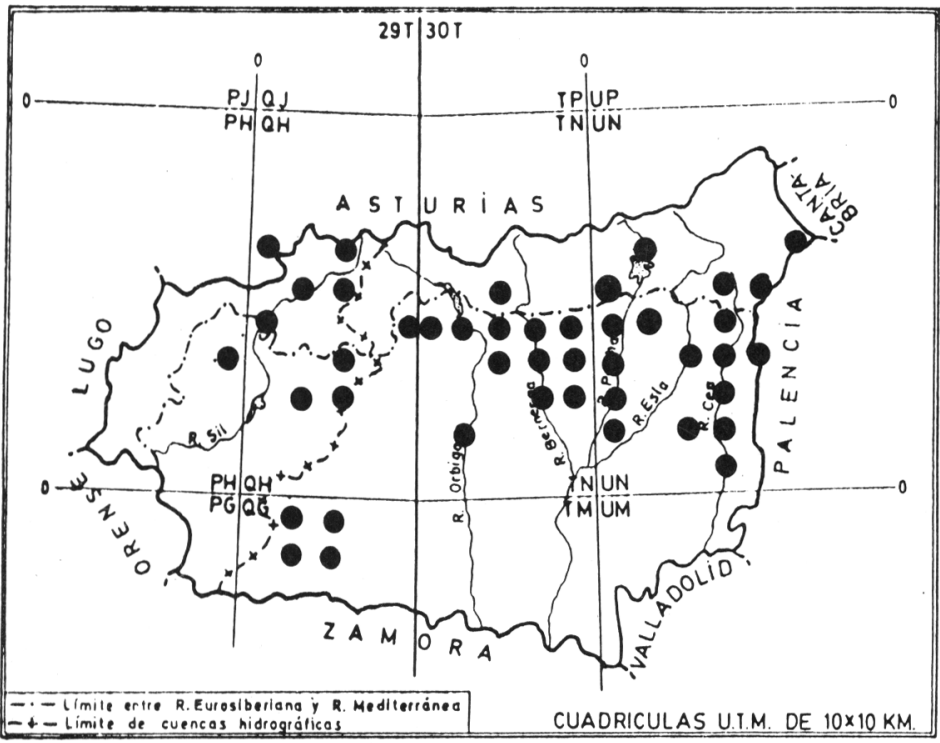

Mapa 13.- Distribución de S. x expectata.

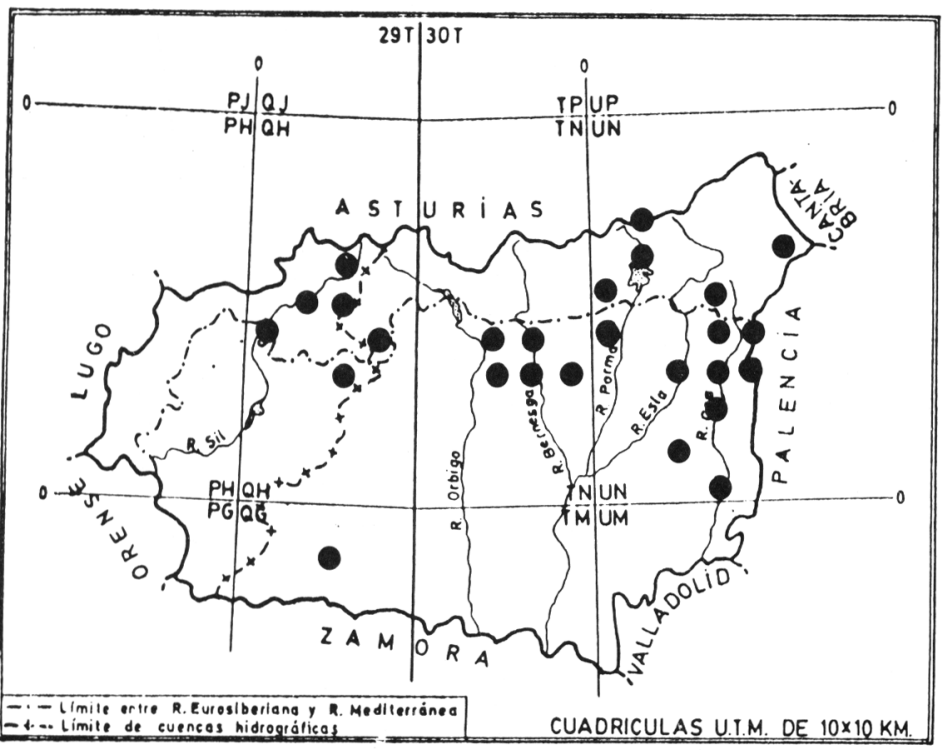

Mapa 14.- Distribución de S. x coenocarpetana. 


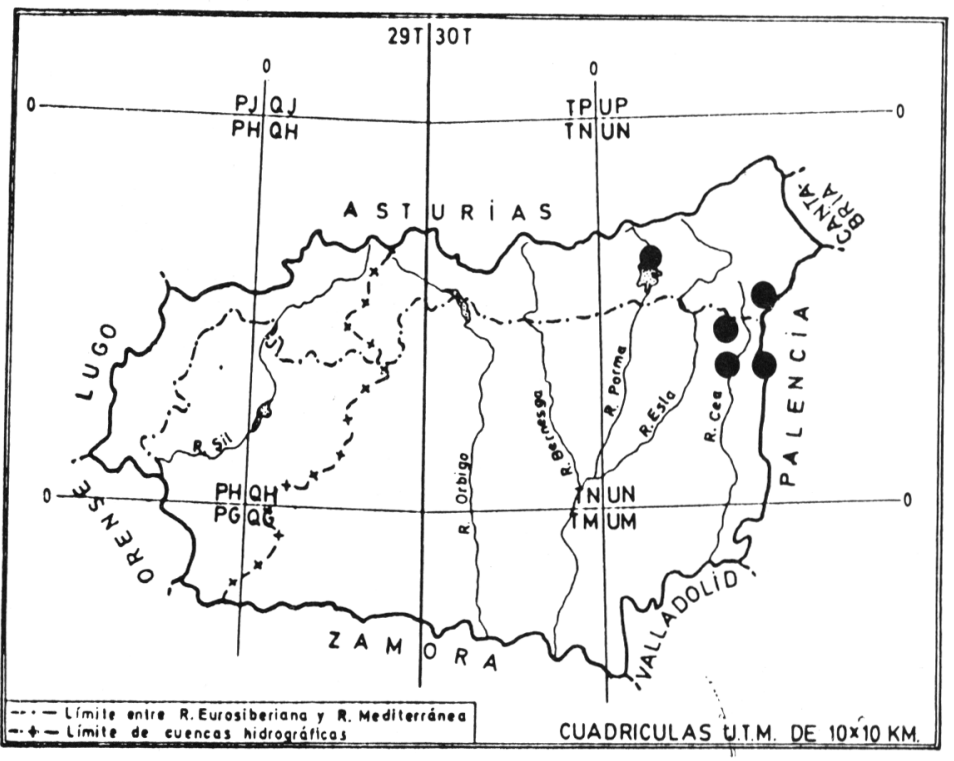

Mapa 15.- Distribución de S. x pormensis

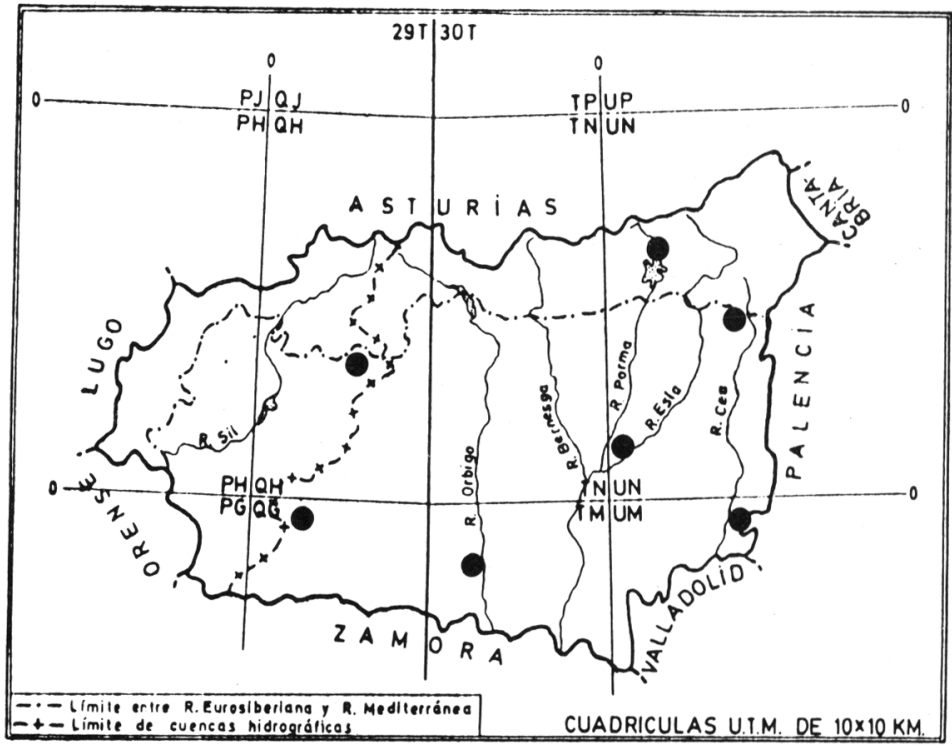

Mapa 16.- Distribución de S. x pormensis 


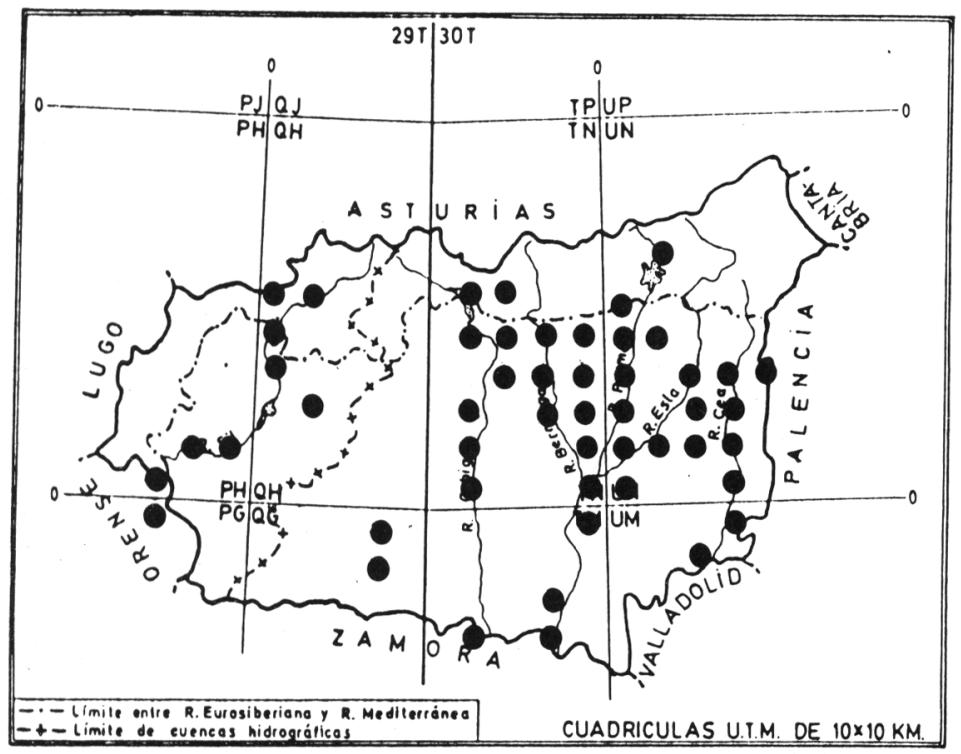

Mapa 17.- Distribución de S. elaeagnos subsp. angustifolia.

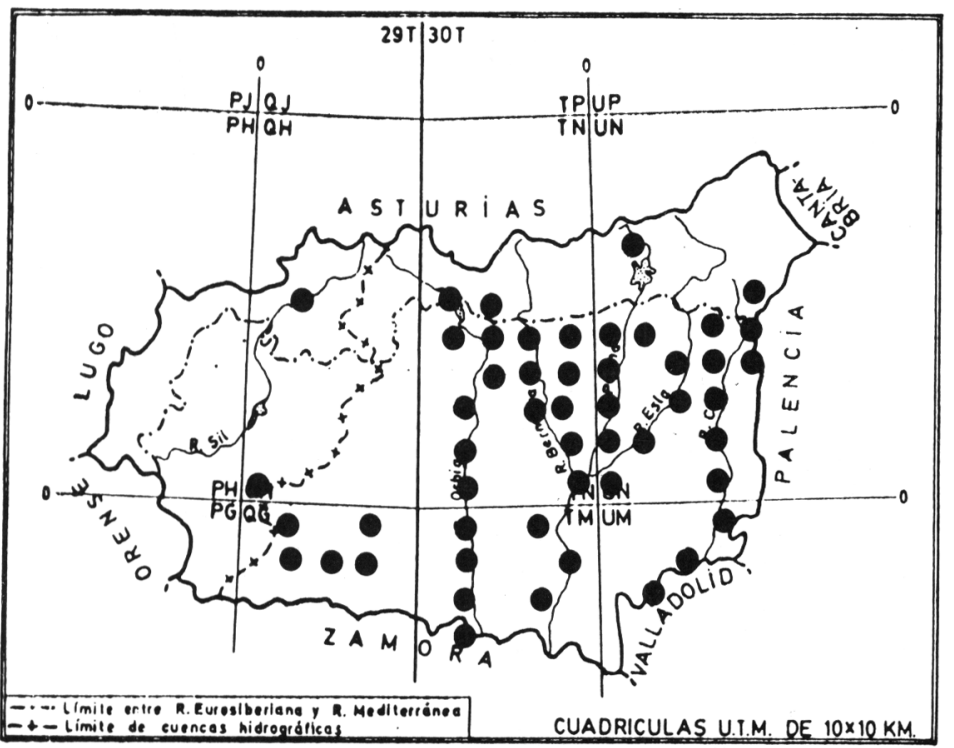

Mapa 18.- Distribución de S. purpurea subsp. lambertiana. 


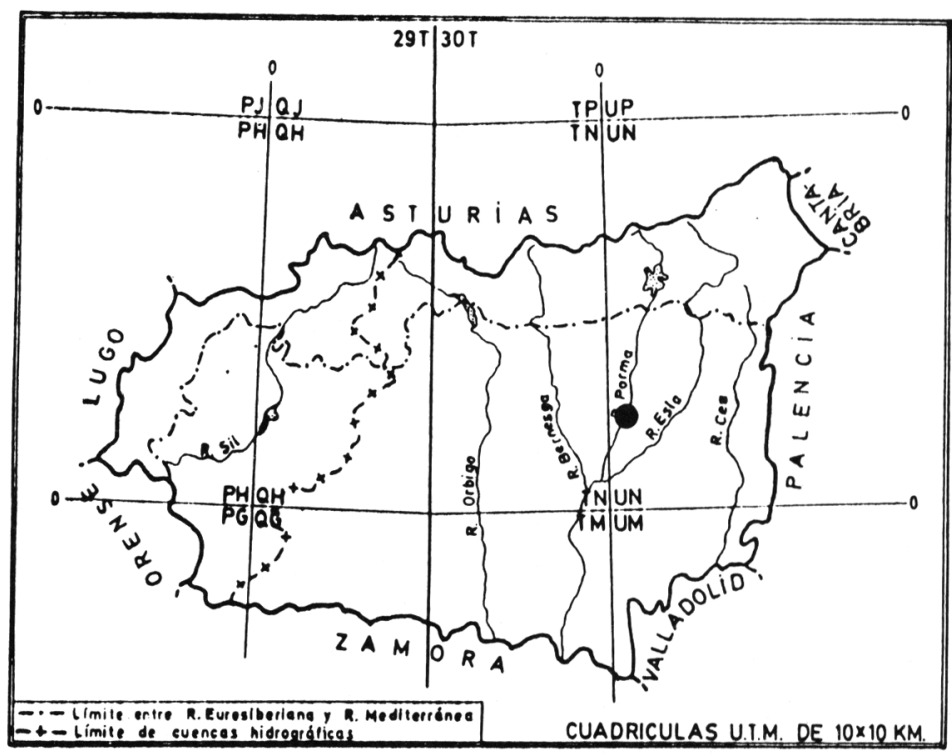

Mapa 19.- Distribución de S. x stipularis.

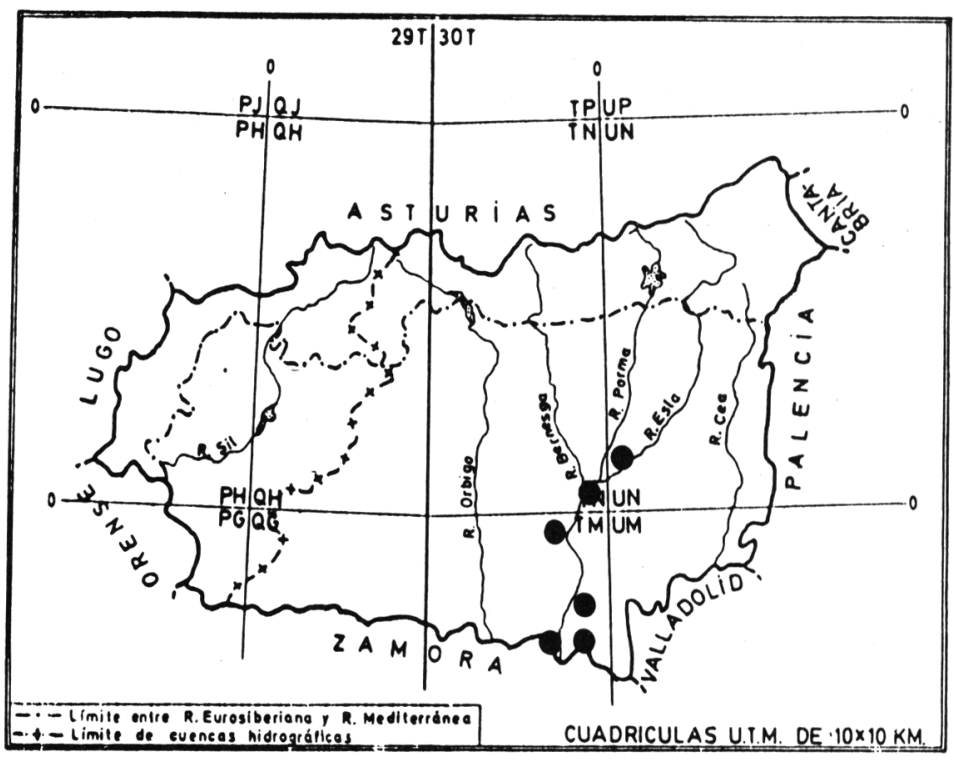

Mapa 20.- Distribución de S. x viridofolia. 


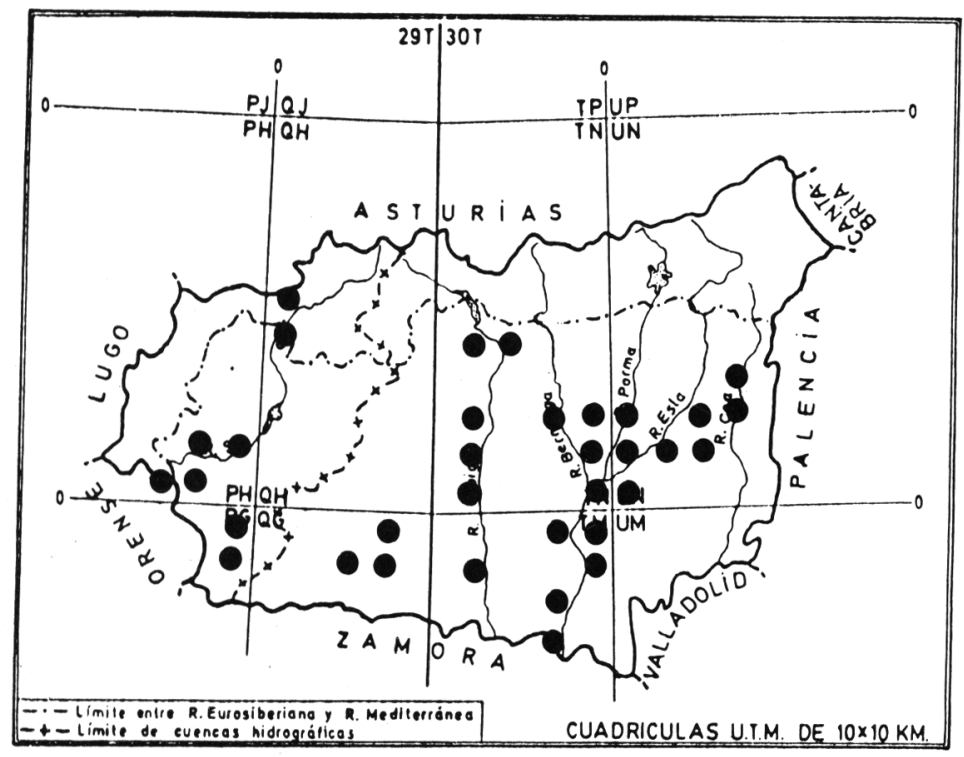

Mapa 21.- Distribución de S. x pseudosalvifolia.

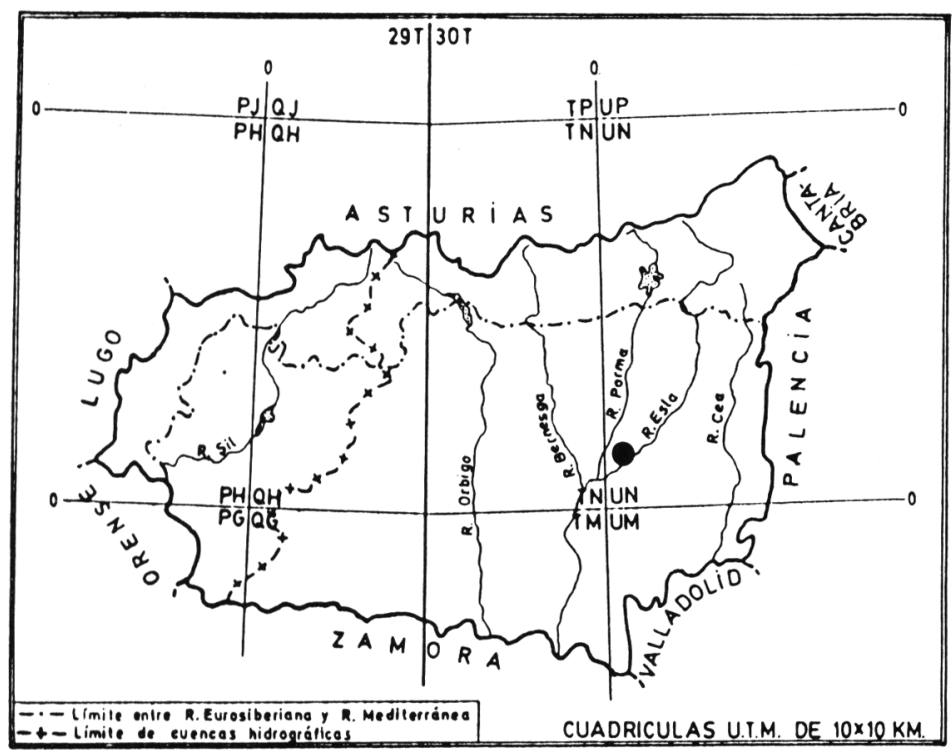

Mapa 22.- Distribución de S. $x$ matritensis. 


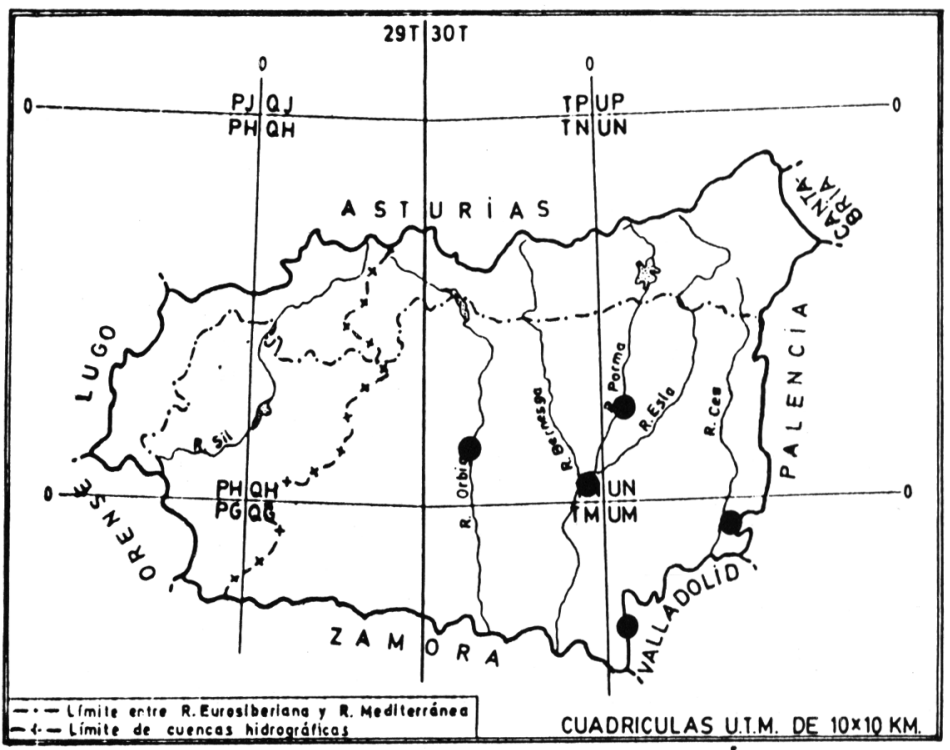

Mapa 23.- Distribución de S. x viciosorum.

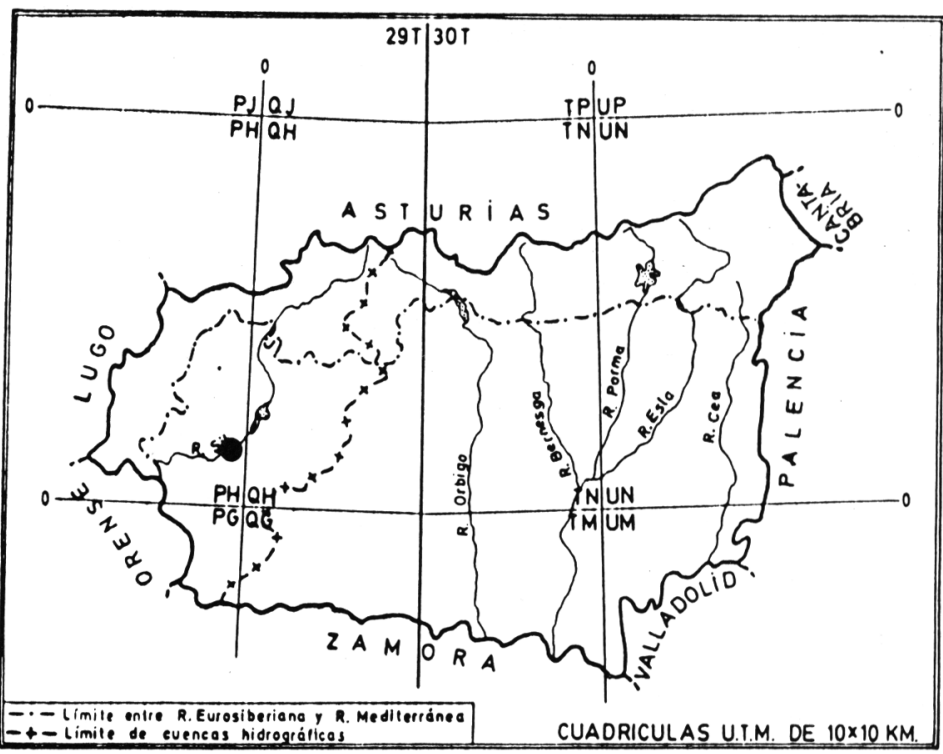

Mapa 24.- Distribución de S. x longissima. 


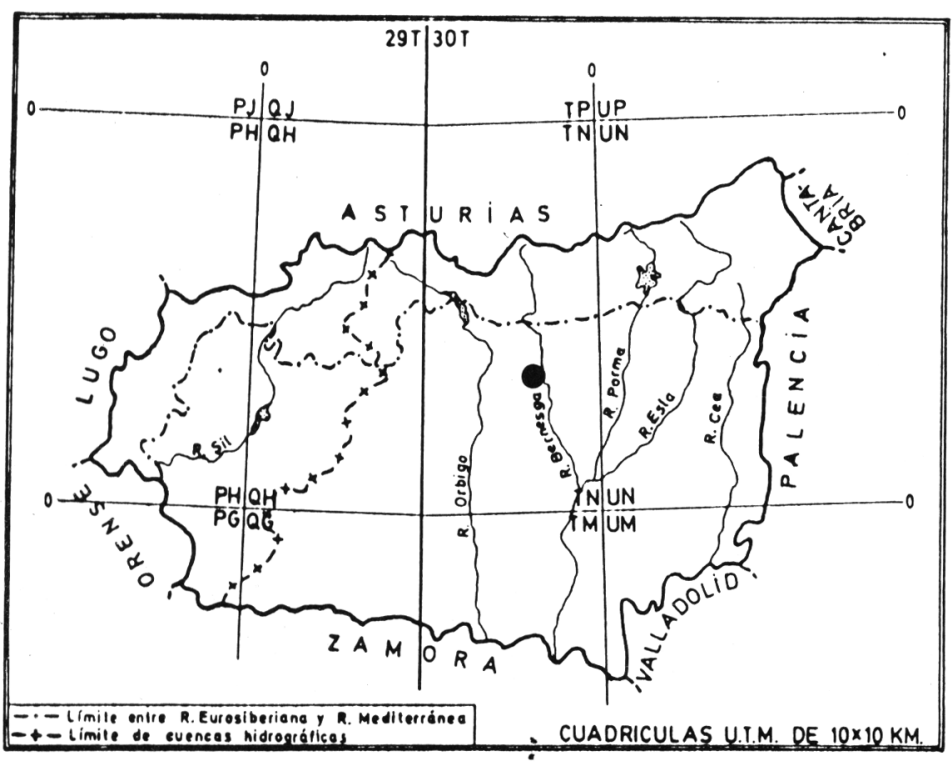

Mapa 25.- Distribución de S. x pseudoelaeagnos.

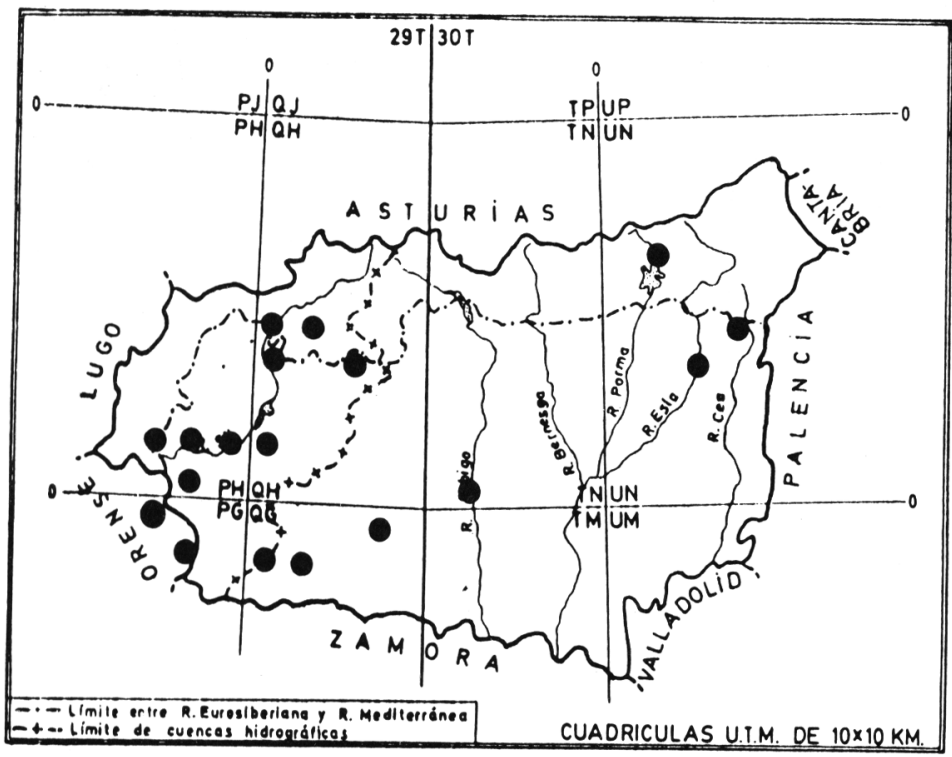

Mapa 26.-.Distribución de S. x multidentata. 


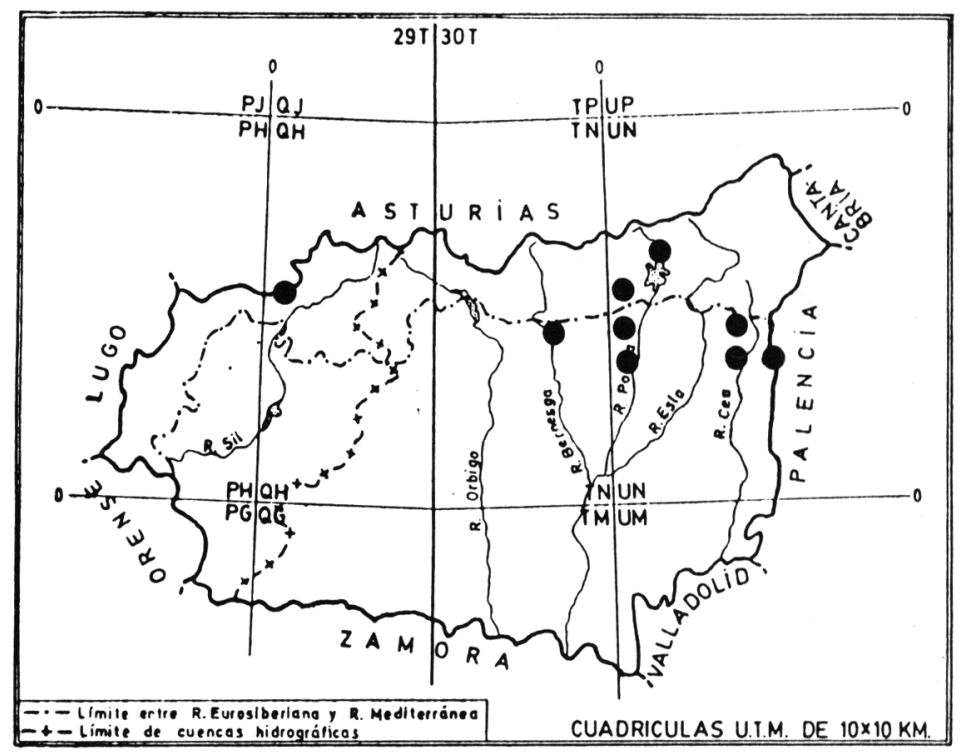

Mapà 27.- Distribución de S. x rijosa. 